\title{
Spatio-temporal variations of soil properties in a plot scale: a case study of soil phosphorus forms and related enzymes
}

\author{
Anna Piotrowska-Długosz ${ }^{1}$ - Joanna Lemanowicz ${ }^{1}$ - Jacek Długosz ${ }^{1}$. \\ Ewa Spychaj-Fabisiak ${ }^{2}$ - Dariusz Gozdowski ${ }^{3} \cdot$ Michał Rybacki $^{1}$
}

Received: 15 December 2014 / Accepted: 9 June 2015 /Published online: 5 July 2015

(C) The Author(s) 2015. This article is published with open access at Springerlink.com

\begin{abstract}
Purpose Spatio-temporal variability in soil properties has long been observed on uniformly managed fields. Understanding the spatial characteristics of soil properties would be helpful in recognizing their relationship and the development of site-specific management techniques. The objective of this study was to determine the spatio-temporal variation of $\mathrm{P}$ forms and related enzymes and their relationship with some physico-chemical properties in a plot scale.

Materials and methods A grid soil sampling $(10 \times 10 \mathrm{~m})$ was used to measure the spatial variation of soil properties across a 0.4-ha field. Soil samples were collected at 50 points from the upper $20 \mathrm{~cm}$ of luvisols in April and August 2007. The total $\left(\mathrm{P}_{\mathrm{T}}\right)$, available $\left(\mathrm{P}_{\mathrm{A}}\right)$, inorganic $\left(\mathrm{P}_{\mathrm{I}}\right)$, organic $\left(\mathrm{P}_{\mathrm{O}}\right)$ phosphorus concentration, and acid $\left(\mathrm{P}_{\mathrm{AC}}\right)$ and alkaline $\left(\mathrm{P}_{\mathrm{AL}}\right)$ phosphatase activity were analyzed. Additionally, total organic carbon (TOC), soil $\mathrm{pH}_{\mathrm{KCl}}$, and clay content were determined. Data were evaluated using classical statistical and geostatistical methods. Results and discussion Both enzyme activities were significantly higher in April than in August, while the $\mathrm{P}_{\mathrm{T}}$ and $\mathrm{P}_{\mathrm{I}}$ concentration were significantly lower. The concentrations
\end{abstract}

Responsible editor: Leo Condron

Anna Piotrowska-Długosz ap03@wp.pl

1 Department of Soil Science and Soil Protection, Faculty of Agriculture and Biotechnology, UTP University of Science and Technology, 6 Bernardyńska St, 85-029 Bydgoszcz, Poland

2 Department of Agricultural Chemistry, UTP University of Science and Technology, 5 Seminaryjna St, 85-326 Bydgoszcz, Poland

3 Department of Experimental Design and Bioinformatics, Warsaw University of Life Sciences, 159 Nowoursynowska St, 02-776 Warsaw, Poland of $\mathrm{P}_{\mathrm{O}}$ and $\mathrm{P}_{\mathrm{A}}$ did not significantly differ between sampling dates. The spherical or mixed (spherical/linear) models with the nugget effect were fitted to the calculated semivariograms. The $\mathrm{P}_{\mathrm{A}}$ and TOC concentrations on both sampling dates as well as $\mathrm{P}_{\mathrm{AC}}$ activity in April were situated in the strong variability class, the $\mathrm{P}_{\mathrm{I}}$ concentration in April revealed a weak spatial variability and the other properties were in the moderate variability class. The clay content revealed a pure nugget effect. The range of the influence that was calculated for the properties ranged from 16.5 to $50.0 \mathrm{~m}$. Kriged maps showed that temporal variability was observed in the spatial patterns of the $\mathrm{P}_{\mathrm{I}}$ and TOC concentrations and $\mathrm{P}_{\mathrm{AC}}$ activity.

Conclusions Results from this study can help us to understand and predict the contribution of internal factors (i.e., soil type) in the total variability of soil properties that can interfere with the influence of soil management practices. The spatiotemporal variability showed that the studied area was temporally unstable and the implication of these findings is that more frequent sampling, at least several times throughout the growing season, must be included in the sampling strategy in order to better understand whether $\mathrm{P}$ forms and related enzymes show any permanent spatial patterns in soil all of the time or whether they are more randomized.

Keywords Geostatistics · Soil phosphatase activity · Soil phosphorus forms $\cdot$ Spatio-temporal variability

\section{Introduction}

Phosphorus (P) is an essential nutrient that is utilized for energy transport and growth by all organisms (Vitousek et al. 2010). It is involved in many critical biological processes, such as energy metabolism, the synthesis of nucleic acids, and photosynthesis (Vance et al. 2003). Phosphorus also 
interacts with other essential elements such as carbon $(\mathrm{C})$ and nitrogen $(\mathrm{N})$ in regulating many biological processes. Phosphorus exists in soil in either inorganic $\left(\mathrm{P}_{\mathrm{I}}\right)$ or organic $\left(\mathrm{P}_{\mathrm{O}}\right)$ forms. Inorganic phosphorus in the soil mainly occurs as plant available forms of $\mathrm{H}_{2} \mathrm{PO}_{4}{ }^{-}$and $\mathrm{HPO}_{4}{ }^{2-}$ adsorbed to the surface of oxides and hydroxides and to organic matter or bound to calcium (Ca) (Olibone and Rosolem 2010). Organic P forms, which occur in soil mainly as inositol phosphates, phospholipids, and nucleic acids, may constitute $20-80 \%$ of the total P in the surface soil (Dalal 1997; Makarov et al. 1997; Turner and Haygarth 2005) and can be a potential source of $P$ for plants and microorganisms only after hydrolysis (Wang et al. 2011). Extracellular phosphomonoesterases are the group of enzymes that can hydrolyze the ester-phosphate bonds in soil organic $P$, which releases phosphate into the soil solution for uptake by plants and microorganisms (Nannipieri et al. 2011). There are two major phosphomonoesterasesacid and alkaline phosphatase, which are classified according to their most effective $\mathrm{pH}$. Both phosphatases significantly contribute to the release of $\mathrm{P}_{\mathrm{I}}$ in the soils and nutrient cycling, and therefore they are enzymes of great agronomic significance (Hui et al. 2013).

Soils are usually supplemented with $\mathrm{P}$ by using either a mineral fertilizer or animal manure. When $\mathrm{P}$ fertilizers are applied at rates that exceed the crop removal rates, the soil $\mathrm{P}$ is elevated to levels that are in excess of the soil's assimilative capacity (Ribaudo et al. 2003). Therefore, excess P that is accumulated in soils is an environmental concern because it can pollute water resources through field runoff and soil leaching (Kaiser et al. 2009). Because of this, a great deal of attention has been focused on the economic effects of deficiency of $\mathrm{P}$, the ecological effects of excessive $\mathrm{P}$, and on optimizing $\mathrm{P}$ fertilization. This is the reason that the spatial variability of this nutrient concentration, which can help in management decisions, should be considered in order to develop a more productive and efficient crop management system.

Soils are characterized by a continuous variation in both space and time (Geypens et al. 1999). The spatial distribution of the soil properties in agricultural systems is affected by both natural conditions (e.g., soil parent material, climate) and by field management (e.g., crop rotation, tillage, fertilization) (Barton et al. 2004; Atreya et al. 2008). Usually, strong spatial dependence of soil properties can be attributed to internal (natural) factors and weak spatial dependence can be attributed to external factors (management factors) (Cambardella et al. 1994). Thus, there is a need to distinguish between the contributions of external and internal factors in the total variability of soil properties in order to evaluate the influence of soil management practices and ultimately lead to more efficient farming practices (Sun et al. 2003). It is important, therefore, to detect, estimate, and map the spatial pattern of soil properties. The scale of soil variation depends on the specific soil characteristic that is being studied. Some soil properties, such as texture, $\mathrm{pH}$, and porosity, are considered to be rather spatially static, while other features such as soil nitrogen $\mathrm{N}$, soil available forms of $\mathrm{P}$ and $\mathrm{K}$, and biological properties are highly spatially variable (Mulla and McBratney 2000; Piotrowska and Długosz 2012). Soil spatial variability can occur across multiple spatial scales, ranging from the micro level (millimeters) to the plot level (meters) and up to the landscape level (kilometers) (Garten et al. 2007; Cobo et al. 2010).

Geostatistics has been proven to be useful to soil science to estimate the spatial variability of soil physical and chemical properties (Katsalirou et al. 2010; Roger et al. 2014; Zhang et al. 2014), soil biochemical properties (Așkin and Kizilkaya 2006; Piotrowska and Długosz 2012), and soil microbial variables and processes (Peigné et al. 2009; Katsalirou et al. 2010). Geostatistics are used to detect, estimate, and map the spatial patterns of regional variables. They are based on modeling and interpreting the semivariograms that relate any dissimilarity between paired data values to the distance between each sample pair (Goovaerts 1998). Semivariogram models provide the necessary information for kriging, a method that is used to interpolate data at non-sampled points (Sebai et al. 2007).

Decisions regarding field management are usually undertaken based on the results of spatial variability that is done once on the area. However, soil properties often reveal high temporal, e.g., seasonal variability and variability between years (Magid and Nielsen 1992; Štípek et al. 2004; Zhao et al. 2009). Taking into account the high temporal soil variability, it was hypothesized that soil properties that were studied in the same area differed in spatial distribution over time, which may result in making a proper recommendation for management practices based on the differences.

The objectives of the study were to (1) obtain essential information on the variability of the soil $\mathrm{P}$ forms concentration and phosphatase activities in an arable field under uniform management and to assess the contribution of random variation in total soil variability, (2) determine whether stability of patterns over two sampling times affects the spatial pattern variability of properties that were studied, (3) examine whether current soil sampling recommendations adequately account for any variability that may be encountered, and (4) examine the relationship between phosphorus forms and related enzymes and some physico-chemical properties on two sampling dates.

\section{Material and methods}

\subsection{Study site and soil sampling}

The research was carried out on a 0.4-ha study site that was selected from an 80-ha agricultural field located in the village 
of Orlinek near Mrocza in the Pomerania and Cuiavia region $\left(53^{\circ} 1531 \mathrm{~N}, 17^{\circ} 3243 \mathrm{E}\right)$ in northwest Poland. The area that was selected for the research is partially covered with typical luvisols (IUSS Working Group WRB 2007). The average air temperature and the sum of rainfall during the growing season (from March to October) in 2007 was $12.9^{\circ} \mathrm{C}$ and $447 \mathrm{~mm}$, while between 1997 and 2007 was $12.3{ }^{\circ} \mathrm{C}$ and $435 \mathrm{~mm}$. The monthly mean values of air temperature and the sum of rainfall in 2007 are presented at Fig. 1. Winter wheat (Triticum aestivum L.) was cultivated after winter rape (Brassica napus L.) as the forecrop. The soil was fertilized with phosphorus $\left[\left(\mathrm{NH}_{4}\right)_{3} \mathrm{PO}_{4}, 200 \mathrm{~kg} \cdot \mathrm{ha}^{-1}, 46 \%\right.$ of $\mathrm{P}]$ and potassium $\left[\mathrm{KCl}, 200 \mathrm{~kg} \cdot \mathrm{ha}^{-1}, 60 \%\right.$ of $\left.\mathrm{K}\right]$ in autumn 2006. Nitrogen as $\mathrm{NH}_{4} \mathrm{NO}_{3}\left(43 \%\right.$ of $\mathrm{N}$ ) at $300 \mathrm{~kg} \cdot \mathrm{ha}^{-1}$ was applied on March 12, 2007 and $250 \mathrm{~kg} \cdot \mathrm{ha}^{-1}$ of CAN (ammonium-calcium nitrate, $\mathrm{N} 27 \%, \mathrm{MgO} 4 \%, \mathrm{CaO} 7 \%$ ) was applied on April 13, 2007. Farmers in Poland make management decisions regarding the application of fertilizer $\mathrm{P}$, based on the Polish Norm recommendations (PN-R-04023). The PN recommendations for soil $\mathrm{P}$ are based on the available $\mathrm{P}$ (Egner-Riehm $\mathrm{P}, \mathrm{P}_{\mathrm{E}-\mathrm{R}}$ ) status of the soil, which has been classified into classes depending on the concentration of $\mathrm{P}$ (Table 1).

Fifty soil samples were collected at the stage of the winter wheat spreading on April 12, 2007 and directly after the harvest on August 6, 2007. The dates of sample collection in this

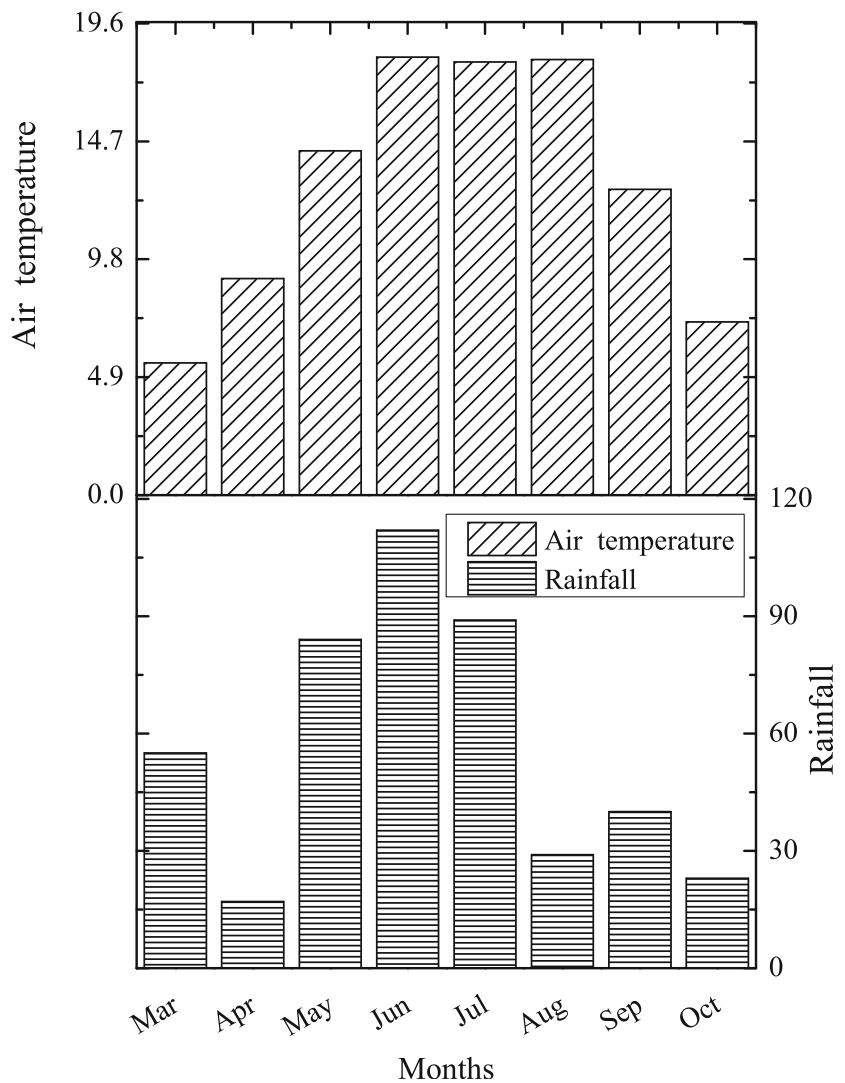

Fig. 1 Distribution of monthly averaged air temperature and monthly sum of rainfall
Table 1 The classes of $\mathrm{P}$ concentration in soil according to the Polish norm (PN-R-04023)

\begin{tabular}{lll}
\hline Class of concentration & $\begin{array}{l}\text { The estimation } \\
\text { of the concentration }\end{array}$ & $\begin{array}{l}\text { The estimation } \\
\text { of the concentration }\end{array}$ \\
\hline V & Very low & $<22$ \\
IV & Low & $23-44$ \\
III & Medium & $45-66$ \\
II & High & $67-88$ \\
I & Very high & $>89$ \\
\hline
\end{tabular}

study were determined in order to estimate the spatial structure of soil properties that originated from various influence of cultivated plant. Spring sampling was chosen to study whether the rest period of plants (in winter) can not only result in changes in the magnitude of soil properties, but can change their spatial structure as well. In turn, the autumn sampling time is the typical sampling period which determine the magnitude of soil properties and their spatial structure after the plant have been cultivated, which is important in soil management (e.g., fertilization), before the sequent plant is cultivated. Soil samples were taken at regular intervals $(10 \mathrm{~m})$ from the $0-20 \mathrm{~cm}$ top layer (plow layer) across the traced plot. The grid pattern used in the study was $90 \mathrm{~m} \times 40 \mathrm{~m}$. Each composite sample comprised $10 \mathrm{sub}$-samples that were taken randomly from a circular area with a radius of $2 \mathrm{~m}$ from the node point. Field-moist samples were sieved (2-mm mesh) and stored in a plastic box at $4{ }^{\circ} \mathrm{C}$ between 2 and 5 days in order to stabilize the microbial activity and then were analyzed for phosphatase activity within 1 week. In order to analyze the physico-chemical properties, the soil samples were air-dried at room temperature and sieved (2-mm mesh).

\subsection{Analysis of soil properties}

The physico-chemical properties were assayed according to standard methods and each sample was analyzed in triplicate (Burt 2004). A particle-size analysis was carried out using the Cassagrande'a method as modified by Prószyński (Mocek et al. 1997) and the sand fraction content was determined using the sieving method. Total organic carbon (TOC) and total nitrogen (TN) content was determined using a dry combustion $\mathrm{CN}$ analyzer (Vario Max $\mathrm{CN}$ ), while soil $\mathrm{pH}(1 \mathrm{M}$ $\mathrm{KCl}$ ) was measured using the potentiometric method in 1:2.5 soil/solution suspensions.

Available $\mathrm{P}$ was determined using the method of EgnerRiehm where $0.1 \mathrm{M}$ ammonium lactate $(\mathrm{pH}=3.7)$ was used as an extracting solution. After the extraction, $\mathrm{P}$ was determined using spectrophotometry after color development with ammonium molybdate and $\mathrm{SnCl}_{2}$ (Egner et al. 1960). Total $\mathrm{P}$ was determined as described by Mehta et al. (1954) by treating soil with concentrated $\mathrm{HCl}$ and then with $0.5 \mathrm{M} \mathrm{NaOH}$ at room 
temperature and at $90{ }^{\circ} \mathrm{C}$. After mixing, the extracts were mineralized with a mixture of concentrated acids: nitric acid (V), perchloric acid (VII), and sulfuric acid (VI) at a ratio of 10:1:4. After mineralization $\mathrm{P}_{\mathrm{T}}$ was assayed by adding two drops of phenolphthalein, ammonia, $5 \mathrm{~N} \mathrm{H}_{2} \mathrm{SO}_{4}$, and ammonium molybdate and $\mathrm{SnCl}_{2}$ to the mineralized solution and the optical density was assayed at $660 \mathrm{~nm}$. $\mathrm{P}_{\mathrm{I}}$ was determined in the same way but without mineralization. The $\mathrm{P}_{\mathrm{O}}$ concentration was calculated as the difference between the total and the $\mathrm{P}_{\mathrm{I}}$ concentration.

The analyses of enzyme activities were performed on $1 \mathrm{~g}$ of fresh, moist, sieved soil samples. To determine the acid (EC 3.1.3.2) and alkaline (EC 3.1.3.1.) phosphatase activities, soil was incubated for $1 \mathrm{~h}$ at $37^{\circ} \mathrm{C}$ with $4 \mathrm{ml}$ of modified universal buffer (MUB) (pH 6.5 for the acid phosphatase and 11.0 for the alkaline one) and $1 \mathrm{ml}$ of $0.115 \mathrm{M} p$-nitrophenylphosphate solution (Tabatabai and Bremner 1969). After incubation, $1 \mathrm{ml}$ of $0.5 \mathrm{M} \mathrm{CaCl}_{2}$ and $4 \mathrm{ml}$ of $0.5 \mathrm{M} \mathrm{NaOH}$ were added to the samples; this was followed by filtration. The concentration of $p$-nitrophenyl was determined photometrically at $400 \mathrm{~nm}$. The enzyme activity values were calculated based on the oven-dry $\left(105^{\circ} \mathrm{C}\right)$ weight of soil.

\subsection{Statistical and geostatistical analyses}

The dataset was analyzed independently twice - first in a classical way in order to investigate the general status of the soil $\mathrm{P}$ forms and phosphatase activity at two sampling times and their links with the chemical-physical soil properties and then within a geostatistics framework in order to investigate the spatial variation of different $P$ forms and related enzymes. The classical statistical parameters such as the mean, maximum, and minimum, standard deviation (SD), coefficient of variation (CV\%), as well as skewness and kurtosis were evaluated using STATISTICA v. 9.0 Software. Normality of the data was determined using the Shapiro-Wilk test. Since the data of all studied properties were normally distributed, we chose not to transform the values before further analyses. In order to evaluate any significant differences between the results that were obtained in April and in August, data were analyzed using the Tukey's test $(p<0.05)$. The relations between the studied properties were estimated using a correlation analysis based on Pearson's correlation coefficients $(p<0.001 ; p<0.01 ; p<0.05)$.

A classification scheme was used to identify the extent of variability for soil properties based on their $\mathrm{CV}[\%]$ values in which values of $0-15,16-35$, and $>36 \%$ indicate little, moderate, and high variability, respectively (Wilding 1985).

Measurements among neighboring observations of the studied variables were assessed for spatial autocorrelation using the Moran's $I$ autocorrelation coefficient (Moran 1948). Spatial autocorrelation is the relationship among the values of a single variable that comes from the geographic arrangement of the areas in which these values occur. It measures the similarity of objects within an area or the degree to which a spatial phenomenon is correlated to itself in space (Jung et al. 2006). Moran's I ranges from +1.0 (strong positive spatial autocorrelation), to 0 (a random pattern) and to -1.0 (strong negative spatial autocorrelation). Moran's $I$ was calculated using a 50-m active lag distance and a 10-m lag interval (ArcGIS 9.3). Significant spatial autocorrelation at the significance level $<0.05$ was found.

A semivariogram was determined for each of the soil $\mathrm{P}$ forms that were studied and phosphatase activity in order to characterize the degree of spatial variability between neighboring samples and the appropriate model function was fit to the semivariogram. The semivariogram $\gamma(h)$ was estimated using the equation:

$\gamma(h)=\frac{1}{2 n(h)} \sum_{i=1}^{n(h)}\left(z_{i}-z_{i+h}\right)^{2}$

where $h$ is the separation distance between locations; $x_{i}$ and $x_{i+h}$ and $z_{i}$ and $z_{i+h}$ are the measured value for the regionalized variables at locations $x_{i}$ or $\mathrm{x}_{i+h}$ and $n(h)$ is the number of pairs at any separation distance $h$ (Burgess and Webster 1980). A semivariogram consists of three basic parameters that describe the spatial structure as $\gamma(h)=\mathrm{C}_{\mathrm{o}}+\mathrm{C} . \mathrm{C}_{\mathrm{o}}$ represents the nugget effect, which is the local variation that occurs at scales smaller than the sampling interval, such as sampling errors, fine-scale spatial variability, and measurement errors. The sill $\left(\mathrm{C}_{\mathrm{o}}+\mathrm{C}\right)$ indicates the maximum (total) semivariance and it is the maximum height of semivariogram curve. The range is the separation distance beyond which two observations are independent of each other (Jung et al. 2006). At separation distances greater than the range, the sampled points are no longer spatially correlated (Mulla and McBratney 2000). The nugget-tosill ratio $[\mathrm{Co} /(\mathrm{Co}+\mathrm{C})] \cdot 100$ can be used to classify the spatial dependence of soils properties (Cambardella et al. 1994). The variable is considered to have strong dependence if the ratio is less than $25 \%$ and it has a moderate spatial dependence if the ratio is between 25 and $75 \%$, otherwise, the variable has a weak spatial dependence (pure nugget effect).

To choose the best models to adjust the empirical variograms, a cross-validation procedure was applied. The criterion for selecting the best fitting models was the mean squared deviation ratio (MSDR), which was calculated from the squared errors and kriging variances (Bishop and Lark 2006). If the model for the variogram is accurate, the MSDR should be close to one (Kerry and Oliver 2007). The punctual kriging was the procedure by which the values of the soil properties were estimated at unsampled locations (Davis 1986). The maps illustrating the spatial variance of the parameters that were determined were drawn based on the semivariograms. The geostatistical calculations were done using Isatis software (Geovariance Co.). 


\section{Results}

\subsection{Descriptive statistics of the properties that were studied}

The data of the properties that were studied follow a normal distribution according to the Shapiro-Wilk test (STATISTICA v. 9.0 Software). The soil that was studied in April and August did not differ significantly in total organic carbon (TOC) $\left(\mathrm{g} \mathrm{kg}^{-1}\right)$, total nitrogen (TN) $\left(\mathrm{g} \mathrm{kg}^{-1}\right)$, or $\mathrm{pH}$ in $\mathrm{KCl}$ at both sampling times (Tukey's test, $p<0.05$ ) (Table 2). The TOC concentration was in the range of $5.5-9.0 \mathrm{~g} \mathrm{~kg}^{-1}$, while the soil $\mathrm{TN}$ concentration ranged from 0.65 to $1.12 \mathrm{~g} \mathrm{~kg}^{-1}$. The soil reaction $\left(\mathrm{pH}_{\mathrm{KCl}}\right)$ was from acid (4.8) to neutral (7.0), with a mean value of 5.4 in April and 5.7 in August. The studied soil is composed of $79.3 \%$ sand, $14.6 \%$ silt, and $6.1 \%$ clay (Table 2 ).

A normal distribution of soil $\mathrm{P}$ forms and phosphatase activity was confirmed by the similar values of means and medians (Table 3). The largest differences between the minimum and maximum values were observed for $\mathrm{P}_{\mathrm{AL}}$, while the lowest range of the data was obtained for the $\mathrm{P}_{\mathrm{A}}$ content and $\mathrm{P}_{\mathrm{AC}}$ activity. The shape of the distribution of the properties that were studied was described by skewness. The skewness values close to $0(0.024)$ indicated that the distribution of the $\mathrm{P}_{\mathrm{O}}$ concentration that was assayed in April was similar to the symmetric distribution. A slight positive skewness was exhibited for $\mathrm{P}_{\mathrm{O}}$ in August, $\mathrm{P}_{\mathrm{I}}$ and $\mathrm{P}_{\mathrm{A}}$ at both sampling times that were studied, as well as in the $\mathrm{P}_{\mathrm{AL}}$ activity in April and $\mathrm{P}_{\mathrm{AC}}$ in August. The right-side asymmetry for the data of the $\mathrm{P}_{\mathrm{AL}}$ that was studied in August and the $\mathrm{P}_{\mathrm{AC}}$ in April as well as the $\mathrm{TOC} / \mathrm{P}_{\mathrm{O}}$ ratio was confirmed by a relatively high value of skewness (between 1.161 and 1.982). The positive kurtosis indicates a relatively peaked distribution whereas the negative one indicates a flat distribution compared to the normal distribution. Soil properties that had a kurtosis close to 0 were total, organic, and inorganic forms of $\mathrm{P}$ on both sampling dates, while the $\mathrm{P}_{\mathrm{A}}$ concentration and $\mathrm{TOC} / \mathrm{P}_{\mathrm{O}}$ on both times of

Table 2 Physico-chemical properties in studied soil

\begin{tabular}{|c|c|c|c|c|}
\hline \multirow[t]{2}{*}{ Soil properties } & \multicolumn{2}{|l|}{ April } & \multicolumn{2}{|l|}{ August } \\
\hline & Mean $( \pm \mathrm{SD})$ & Range & Mean $( \pm \mathrm{SD})$ & Range \\
\hline TOC $\left(\mathrm{g} \mathrm{kg}^{-1}\right)$ & $7.3( \pm 0.91)$ & $5.5-9.0$ & $7.5( \pm 0.85)$ & $5.8-9.0$ \\
\hline $\mathrm{TN}\left(\mathrm{g} \mathrm{kg}^{-1}\right)$ & $0.80( \pm 0.07)$ & $0.68-0.99$ & $0.80( \pm 0.11)$ & $0.65-1.12$ \\
\hline $\mathrm{pH}_{\mathrm{KCl}}$ & $5.4( \pm 0.36)$ & $4.8-6.8$ & $5.7( \pm 0.44)$ & $5.0-7.0$ \\
\hline Sand $(\%)$ & - & - & $79.3( \pm 2.3)$ & $75-85$ \\
\hline Silt (\%) & - & - & $14.6( \pm 2.1)$ & $11-19$ \\
\hline Clay $(\%)$ & - & - & $6.1( \pm 1.3)$ & 4-9 \\
\hline
\end{tabular}

TOC total organic carbon, $T N$ total nitrogen, $p H_{K C l}$ soil $\mathrm{pH}$ in $1 \mathrm{M} \mathrm{KCl}$, $S D$ standard deviation sampling indicated a higher leptokurtic distribution as well as the $\mathrm{P}_{\mathrm{AL}}$ activity in August and the $\mathrm{P}_{\mathrm{AC}}$ activity in April. The value of the $\mathrm{TOC} / \mathrm{P}_{\mathrm{O}}$ ratio (below 200:1) indicated a process of mineralization (Stevenson 1986) and did not show any significant difference between both sampling dates (Table 3).

Among the studied properties, the $\mathrm{P}_{\mathrm{O}}$ content that was studied in August as well as the $\mathrm{TOC} / \mathrm{P}_{\mathrm{O}}$ ratio and the $\mathrm{P}_{\mathrm{AL}}$ activity from both sampling dates tended to be the most variable with a $\mathrm{CV}$ values between 37.7 and $46.3 \%$. The other properties studied showed a moderate variability as was indicated by the $\mathrm{CV}$ values between 15.5 and $33.7 \%$ (Table 3).

\subsection{Geostatistical analysis of the spatial variability of soil properties}

Significant spatial autocorrelation $(p<0.05)$ was found for the $\mathrm{P}_{\mathrm{T}}$ content in April, $\mathrm{P}_{\mathrm{AL}}$ activity in August and $\mathrm{P}_{\mathrm{I}}, \mathrm{P}_{\mathrm{A}}$ concentration, $\mathrm{P}_{\mathrm{AC}}$ activity, $\mathrm{TOC}$ concentration, and $\mathrm{pH}_{\mathrm{KCl}}$ on both sampling dates. The spatial autocorrelation was generally positive but was low with Moran's $I$ ranging between 0.007 and 0.544. Only in the case of $\mathrm{P}_{\mathrm{O}}$ and $\mathrm{P}_{\mathrm{T}}$ determined in August was Moran's $I$ index negative, suggesting that dissimilar values occur near one another (Table 4).

To characterize the spatial variability of the properties that were spatially autocorrelated, spherical, linear or mixed (spherical/linear), models with the nugget effect were fitted to the semivariograms that were calculated (Table 5, Figs. 2, $3,4)$. The exception was the clay content which revealed the total random variability (pure nugget effect) (Fig. 5). The data indicated that only 11.2 and $8.9 \%$ of the $\mathrm{P}_{\mathrm{A}}$ concentration, and 7.7 and $9.6 \%$ of TOC concentration in April and August, respectively, as well as $7.2 \%$ of $\mathrm{P}_{\mathrm{AC}}$ activity in April was due to random variability and that the structural variance accounted for about $90 \%$ (Table 5). The spatial variability of the variables that were studied was categorized into three classes based on the percentage of total variance (sill) presented as a random variance $[\mathrm{Co} / \mathrm{Co}+\mathrm{C}, \%]$ (Table 5). The nugget/ sill ratio of $\mathrm{P}_{\mathrm{A}}(11.2 \%$ in April and $8.9 \%$ in August) and TOC (7.7\% in April and $9.6 \%$ in August), as well as of $\mathrm{P}_{\mathrm{AC}}$ activity in April (7.2 \%) indicated a strong spatial variability. Nugget semivariance for $\mathrm{P}_{\mathrm{I}}$ assayed in April was large compared with the total variance $(78.1 \%$ of sill), which suggests a weak spatial structure. For the $\mathrm{P}_{\mathrm{T}}$ content in April, the $\mathrm{P}_{\mathrm{I}}$ concentration in August, the $\mathrm{P}_{\mathrm{AL}}$ activity on both sampling dates, the $\mathrm{P}_{\mathrm{AC}}$ activity in August and $\mathrm{pH}_{\mathrm{KCl}}$ in April and August, the best theoretical variogram models showed a contribution of nugget $(\mathrm{Co})$ in sill $(\mathrm{Co}+\mid \mathrm{C})$ at the level of 35.0-68.9\%, which indicates a moderate spatial structure.

The ranges of influence that were calculated for the correlated variables ranged between 16.5 and $50.0 \mathrm{~m}$ (Table 5, Figs. 2, 3, 4). The $\mathrm{P}_{\mathrm{AL}}$ activity and $\mathrm{pH}_{\mathrm{KCl}}$ in August and as well as clay content was not spatially dependent at the scale of 
Table 3 Statistics of soil properties $(n=50)$

\begin{tabular}{|c|c|c|c|c|c|c|c|c|c|c|}
\hline Property & Sampling month & Min & Max & Mean & Geometric mean & Median & $\mathrm{SD}$ & Skewness & Kurtosis & $\mathrm{CV}(\%)$ \\
\hline \multirow[t]{2}{*}{$\mathrm{P}_{\mathrm{T}}\left(\mathrm{mg} \mathrm{kg}^{-1}\right)$} & April $^{\mathrm{a}}$ & 130 & 626 & $390 \mathrm{~b}$ & 374 & 390 & 105 & -0.192 & -0.044 & 26.9 \\
\hline & August & 209 & 657 & $447 \mathrm{a}$ & 434 & 444 & 102 & -0.317 & -0.170 & 22.8 \\
\hline \multirow[t]{2}{*}{$\mathrm{P}_{\mathrm{O}}\left(\mathrm{mg} \mathrm{kg}^{-1}\right)$} & April & 61 & 343 & 209 & 198 & 207 & 64 & 0.024 & -0.140 & 30.6 \\
\hline & August & 83 & 436 & 204 & 190 & 186 & 77 & 0.661 & 0.219 & 37.7 \\
\hline \multirow[t]{2}{*}{$\mathrm{P}_{\mathrm{I}}\left(\mathrm{mg} \mathrm{kg}^{-1}\right)$} & April $^{\mathrm{a}}$ & 69 & 319 & $181 \mathrm{~b}$ & 171 & 176 & 60 & 0.510 & 0.211 & 33.1 \\
\hline & August & 81 & 441 & $243 \mathrm{a}$ & 229 & 239 & 82 & 0.481 & 0.104 & 33.7 \\
\hline \multirow[t]{2}{*}{$\mathrm{P}_{\mathrm{A}}\left(\mathrm{mg} \mathrm{kg}^{-1}\right)$} & April & 41 & 87 & 58 & 57 & 56 & 9.4 & 0.772 & 1.269 & 16.3 \\
\hline & August & 34 & 96 & 59 & 58 & 57 & 11 & 0.466 & 1.176 & 19.2 \\
\hline \multirow[t]{2}{*}{$\mathrm{P}_{\mathrm{O}} / \mathrm{P}_{\mathrm{T}}$} & April $^{\mathrm{a}}$ & 0.24 & 0.67 & $0.54 \mathrm{a}$ & 0.53 & 0.54 & 0.08 & -1.384 & 2.662 & 15.5 \\
\hline & August & 0.18 & 0.80 & $0.46 \mathrm{~b}$ & 0.44 & 0.45 & 0.13 & 0.117 & -0.356 & 28.0 \\
\hline \multirow[t]{2}{*}{$\mathrm{TOC} / \mathrm{P}_{\mathrm{O}}$} & April & 20.2 & 108.2 & 39.2 & 36.4 & 37.3 & 17.4 & 1.982 & 5.186 & 44.3 \\
\hline & August & 16.6 & 103.9 & 42.3 & 39.4 & 40.6 & 17.0 & 1.230 & 2.178 & 40.3 \\
\hline \multirow[t]{2}{*}{$\mathrm{P}_{\mathrm{AL}}\left(\mathrm{mM} p \mathrm{NP} \mathrm{kg}{ }^{-1} \mathrm{~h}^{-1}\right)$} & April $^{\mathrm{a}}$ & 0.14 & 1.28 & $0.58 \mathrm{a}$ & 0.52 & 0.54 & 0.250 & 0.585 & 0.433 & 43.1 \\
\hline & August & 0.14 & 0.97 & $0.38 \mathrm{~b}$ & 0.35 & 0.35 & 0.176 & 1.373 & 2.106 & 46.3 \\
\hline \multirow[t]{2}{*}{$\mathrm{P}_{\mathrm{AC}}\left(\mathrm{mM} p \mathrm{NP} \mathrm{kg}{ }^{-1} \mathrm{~h}^{-1}\right)$} & April $^{\mathrm{a}}$ & 1.47 & 4.00 & $2.23 \mathrm{a}$ & 2.19 & 2.19 & 0.462 & 1.161 & 3.268 & 20.7 \\
\hline & August & 0.97 & 2.50 & $1.69 \mathrm{~b}$ & 1.65 & 1.68 & 0.379 & 0.314 & -0.539 & 22.4 \\
\hline
\end{tabular}

$P_{T}$ total phosphorus, $P_{O}$ organic phosphorus, $P_{I}$ inorganic phosphorus, $P_{A}$ available phosphorus, $P_{A L}$ alkaline phosphatase activity, $P_{A C}$ acid phosphatase activity, $S D$ standard deviation, $C V(\%)$ coefficient of variation

${ }^{a}$ Significant differences between April and August (Tukey's test, $p<0.05$ )

our sampling grid. Since the range is the maximum distance over which results are correlated (Bergstrom et al. 1998a), the

Table 4 Moran's $I$ for properties studied

\begin{tabular}{|c|c|c|c|c|}
\hline Property & $\begin{array}{l}\text { Sampling } \\
\text { month }\end{array}$ & Moran's I & $Z$ score & $P$ value \\
\hline \multirow[t]{2}{*}{$\mathrm{P}_{\mathrm{T}}\left(\mathrm{mg} \mathrm{kg}^{-1}\right)$} & April & 0.125 & 3.027 & 0.0025 \\
\hline & August & -0.004 & 0.339 & 0.7350 \\
\hline \multirow[t]{2}{*}{$\mathrm{P}_{\mathrm{O}}\left(\mathrm{mg} \mathrm{kg}^{-1}\right)$} & April & 0.058 & 1.616 & 0.1060 \\
\hline & August & -0.024 & -0.071 & 0.9435 \\
\hline \multirow[t]{2}{*}{$\mathrm{P}_{\mathrm{A}}\left(\mathrm{mg} \mathrm{kg}^{-1}\right)$} & April & 0.187 & 4.365 & 0.0000 \\
\hline & August & 0.157 & 3.737 & 0.0002 \\
\hline \multirow[t]{2}{*}{$\mathrm{P}_{\mathrm{I}}\left(\mathrm{mg} \mathrm{kg}^{-1}\right)$} & April & 0.125 & 3.017 & 0.0026 \\
\hline & August & 0.143 & 2.127 & 0.0032 \\
\hline \multirow[t]{2}{*}{$\mathrm{P}_{\mathrm{AC}}\left(\mathrm{mM} p \mathrm{NP} \mathrm{kg} \mathrm{h}^{-1} \mathrm{~h}^{-1}\right)$} & April & 0.278 & 6.221 & 0.0000 \\
\hline & August & 0.233 & 5.371 & 0.0000 \\
\hline \multirow[t]{2}{*}{$\mathrm{P}_{\mathrm{AL}}\left(\mathrm{mM} p \mathrm{NP} \mathrm{kg} \mathrm{h}^{-1} \mathrm{~h}^{-1}\right)$} & April & 0.007 & 0.581 & 0.5612 \\
\hline & August & 0.243 & 5.437 & 0.0000 \\
\hline \multirow[t]{2}{*}{ TOC $\left(\mathrm{g} \mathrm{kg}^{-1}\right)$} & April & 0.544 & 7.469 & 0.0000 \\
\hline & August & 0.461 & 6.365 & 0.0000 \\
\hline \multirow[t]{2}{*}{$\mathrm{pH}_{\mathrm{KCl}}$} & April & 0.241 & 3.498 & 0.0000 \\
\hline & August & 0.319 & 4.580 & 0.0000 \\
\hline Clay (\%) & August & 0.108 & 1.718 & 0.0860 \\
\hline
\end{tabular}

$P_{T}$ total phosphorus, $P_{O}$ organic phosphorus, $P_{I}$ inorganic phosphorus, $P_{A}$ available phosphorus, $P_{A L}$ alkaline phosphatase activity, $P_{A C}$ acid phosphatase activity, TOC total organic carbon, $p H_{K C l}$ soil $\mathrm{pH}$ in $1 \mathrm{M}$ $\mathrm{KCl}$ sampling scheme for the properties that were studied could be less intensive (about $20 \mathrm{~m}$ ) than this accepted in the study.

\subsection{Temporal changes of data and their spatial patterns}

Significant differences between the properties studied in April and August were observed for the $\mathrm{P}_{\mathrm{T}}$ and $\mathrm{P}_{\mathrm{I}}$ concentration, the $\mathrm{P}_{\mathrm{O}} / \mathrm{P}_{\mathrm{T}}$ ratio, and the phosphatase activity (Tukey's test, $p<0.05$, Table 3). Based on the mean value, both the $\mathrm{P}_{\mathrm{T}}$ and $\mathrm{P}_{\mathrm{I}}$ concentrations were higher in August than in April (13 and $25 \%$ ), while both $\mathrm{P}_{\mathrm{AL}}$ and $\mathrm{P}_{\mathrm{AC}}$ activities were significantly higher in April compared to August (34 and $24 \%$, respectively). The $\mathrm{P}_{\mathrm{O}} / \mathrm{P}_{\mathrm{T}}$ ratio was $15 \%$ lower in August than in April.

The main application of geostatistics to soil science has been to estimate and map soil property values in unsampled areas. The spatial pattern of the spatially autocorrelated studied properties are presented in Figs. 6, 7, and 8. In each figure, light shading represents the highest values while darker shading is associated with the lowest values. The kriged map of soil $\mathrm{P}_{\mathrm{A}}$ in August corresponds to the ranges of each PN-R04023 (1996) class that is shown in Fig. 6a. The concentration of $\mathrm{P}_{\mathrm{A}}$ did not show considerable differences across the studied area and most of the area was in the medium class of the content (III class of the content according to Table 1), which suggests that further application of $\mathrm{P}$ fertilizers on this area should be no higher than that of the cultivated plant demand (Kulczycki 2012). A higher concentration of $P_{A}$ (II class) was only observed on two small areas that are situated to the southwest and southeast. A low content of $\mathrm{P}_{\mathrm{A}}$ (IV class) was only 
Table 5 Parameters of variogram models

\begin{tabular}{|c|c|c|c|c|c|c|c|c|}
\hline Property & Sampling month & Model & Nugget (Co) & Sill $(\mathrm{Co}+\mathrm{C})$ & $\mathrm{Co} /(\mathrm{Co}+\mathrm{C})[\%]$ & Range (m) & MSDR & SD \\
\hline $\mathrm{P}_{\mathrm{T}}$ & April & Sph, L, NE & 0.0054 & 0.0114 & 47.4 & 22.0 & 0.996 & M \\
\hline \multirow[t]{2}{*}{$\mathrm{P}_{\mathrm{A}}$} & April & Sph, L, NE & 7.3 & 64.8 & 11.2 & 16.5 & 0.976 & S \\
\hline & August & Sph, NE & 12.0 & 135.5 & 8.9 & 27.5 & 0.995 & S \\
\hline \multirow[t]{2}{*}{$P_{I}$} & April & Sph, NE & 0.0025 & 0.0032 & 78.1 & 25.0 & 0.994 & W \\
\hline & August & Sph, NE & 0.0034 & 0.0069 & 49.3 & 39.0 & 1.078 & M \\
\hline \multirow[t]{2}{*}{$\mathrm{P}_{\mathrm{AC}}$} & April & Sph, NE & 0.005 & 0.069 & 7.2 & 31.0 & 1.163 & S \\
\hline & August & Sph, NE & 0.009 & 0.0257 & 35.0 & 35.0 & 1.113 & M \\
\hline \multirow[t]{2}{*}{$\mathrm{P}_{\mathrm{AL}}$} & April & Sph, NE & 0.120 & 0.185 & 64.9 & 22.0 & 1.112 & M \\
\hline & August & $\mathrm{L}, \mathrm{NE}$ & 0.042 & 0.061 & 68.9 & - & 1.579 & M \\
\hline \multirow[t]{2}{*}{ TOC } & April & Sph, NE & 0.06 & 0.78 & 7.7 & 50.0 & 0.998 & $\mathrm{~S}$ \\
\hline & August & Sph, NE & 0.08 & 0.83 & 9.6 & 48.0 & 1.059 & S \\
\hline \multirow[t]{2}{*}{$\mathrm{pH}_{\mathrm{KCl}}$} & April & Sph, NE & 0.072 & 0.173 & 41.6 & 42.5 & 1.002 & M \\
\hline & August & $\mathrm{L}, \mathrm{NE}$ & 0.155 & 0.240 & 64.6 & - & 1.006 & M \\
\hline Clay & August & NE & 0.97 & 0.97 & 100.0 & - & 1.045 & $\mathrm{PNE}$ \\
\hline
\end{tabular}

Sph spherical, $L$ linear, $N E$ nugget effect, $M S D R$ mean squared deviation ratio, $S D$ spatial dependence, $S$ strong, $M$ moderate, $W$ weak, $P N E$ pure nugget effect, $P_{T}$ total phosphorus, $P_{I}$ inorganic phosphorus, $P_{A}$ available phosphorus, $P_{A L}$ alkaline phosphatase activity, $P_{A C}$ acid phosphatase activity, TOC total organic carbon, $p H_{K C l}$ soil $\mathrm{pH}$ in $1 \mathrm{M} \mathrm{KCl}$

observed in a 60-m-long and 10-30-m-wide strip of the studied area. Because the spatial distribution of the $\mathrm{P}_{\mathrm{A}}$ concentration in April was similar to that which was observed in
August, we are not presenting it. The concentration of $P_{I}$ in April was the highest along the western part of the transect at a length of 0-20 m and over the entire width of the area. The
Fig. 2 Experimental semivariograms of a $\mathrm{P}_{\mathrm{A}}$ concentration in April, $\mathbf{b} \mathrm{P}_{\mathrm{A}}$ concentration in August, $\mathbf{c} \mathrm{P}_{\mathrm{I}}$ concentration in April, and $\mathbf{d} \mathrm{P}_{\mathrm{I}}$ concentration in August

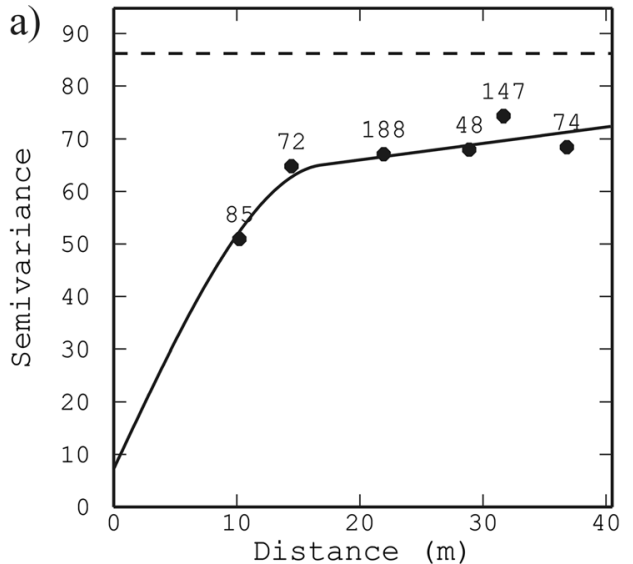

c)

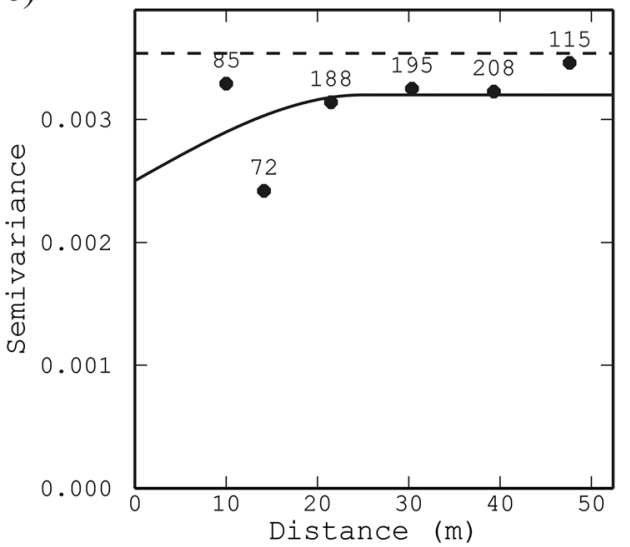

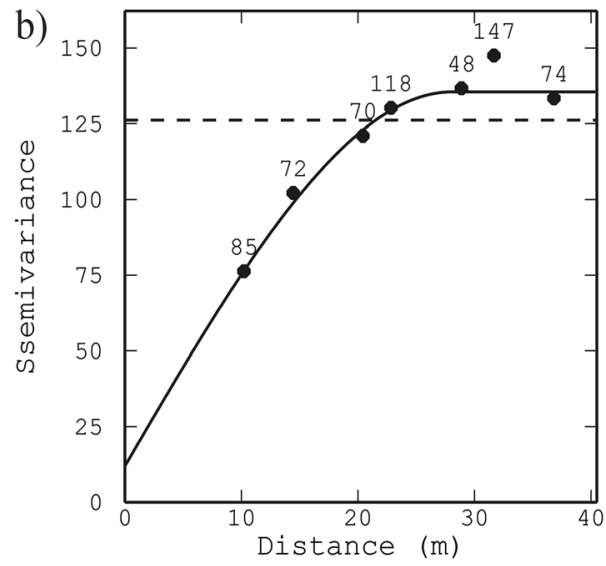

d)

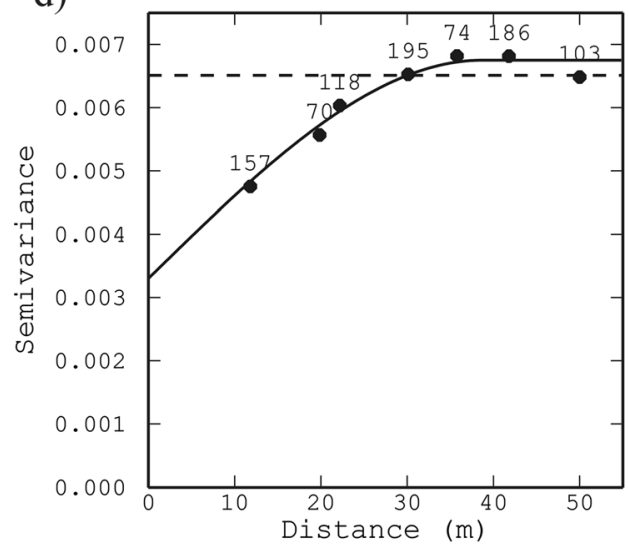


Fig. 3 Experimental semivariograms of a $\mathrm{P}_{\mathrm{AC}}$ activity in April, $\mathbf{b} \mathrm{P}_{\mathrm{AC}}$ activity in August, and $\mathbf{c} \mathrm{P}_{\mathrm{AL}}$ activity in August a)

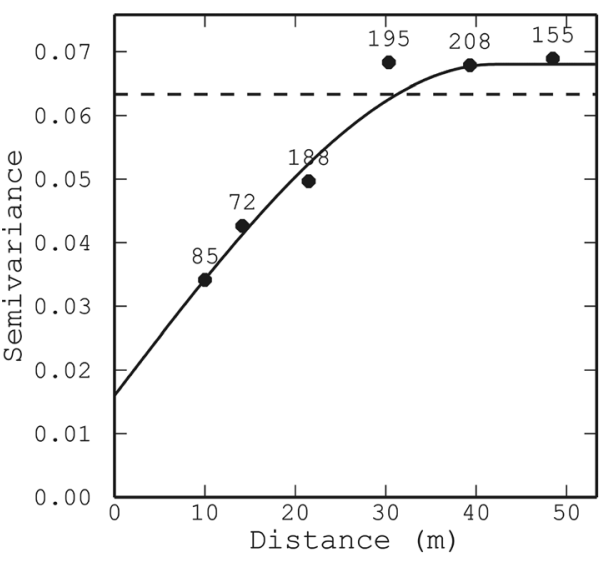

b)

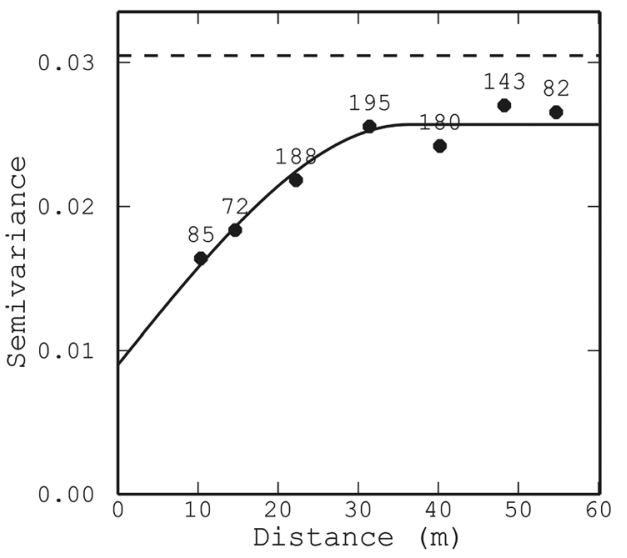

c)

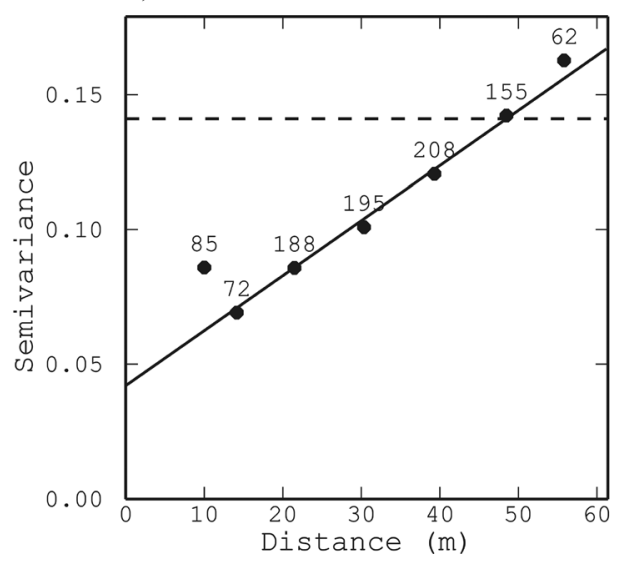

lowest concentration of $\mathrm{P}_{\mathrm{I}}$ was located in the southeast quadrant of the studied plot (50-90-m long and $0-25-\mathrm{m}$ wide) (Fig. 6b). The highest concentration of $\mathrm{P}_{\mathrm{I}}$ in August was distributed in the same area as in April, while the lowest content of this variable was in a band from the south to the northwest (40-60-m long) to the northwest part of the plot (Fig. 6c). Soil $\mathrm{P}_{\mathrm{AC}}$ activity in April was homogenously distributed in the area that was studied with only small pockets of higher or lower values situated along the western part of the plot that was studied (Fig. 7a). This enzyme was generally lower and more differentiated in the soil samples that were collected in August than in April. The highest values of $\mathrm{P}_{\mathrm{AC}}$ in August were observed in the northeast corner of the area, while the lowest was located in the northwest part of the field (Fig. 7b). The $\mathrm{P}_{\mathrm{AL}}$ activity data in August was more differentiated than that of the $\mathrm{P}_{\mathrm{AC}}$ on this sampling date (Fig. 7c). The highest activity of this enzyme was located along the western part of the field and along the northern edge at a length of 35-65 m, while the lowest values of this activity was observed in a small area that was located at a length of $70-80 \mathrm{~m}$ and at a width of $20-35 \mathrm{~m}$. The highest TOC concentration in April (Fig. 8a) was observed over the entire width of the eastern part of the area and in one point located at a length of $30 \mathrm{~m}$ and a width of
$10 \mathrm{~m}$. An area with the lowest TOC concentration was situated in the northwest corner of the field. The highest TOC concentration in August (Fig. 8b) was located at the southwest and southeast corners of the field, while the lowest data set was found in a band across the field from the northwest (40-m width and 15-30-m long) to south-central (40-60-m long). The spatial distribution of TOC concentration at both sampling times was similar to that of the $\mathrm{N}_{\text {TOT }}$ content that was presented earlier (Piotrowska 2011; Piotrowska-Długosz et al. 2013), while spatial structure of TOC in August was similar to $\mathrm{P}_{\mathrm{I}}$ concentration (Figs. 6c, 8b). The distribution of $\mathrm{pH}_{\mathrm{KCl}}$ data was similar at both sampling times (Fig. $8 \mathrm{c}-\mathrm{d}$ ). The values of this property decreased progressively from the northwest corner of the area to the southeast part of the field (up to 70-m long).

\subsection{Correlation between the properties that were studied}

The highest significant correlation coefficients $(p<0.001)$ were shown between $\mathrm{P}_{\mathrm{T}}$ and $\mathrm{P}_{\mathrm{I}}$ and $\mathrm{P}_{\mathrm{O}}$ in April $(p=0.829$ and $p=0.853$ ) and between $\mathrm{P}_{\mathrm{AL}}$ activity and $\mathrm{pH}_{\mathrm{KCl}}$ in $\mathrm{Au}$ gust ( $p=0.833$ ) (Table 6). A significant and positive relationship was found between $\mathrm{P}_{\mathrm{O}}$ and $\mathrm{P}_{\mathrm{T}}$ and $\mathrm{P}_{\mathrm{O}}$ and $\mathrm{P}_{\mathrm{I}}$ concentrations in August. An analysis of the correlation 
Fig. 4 Experimental semivariograms of a TOC concentration in April, b TOC concentration in August, $\mathbf{c} \mathrm{pH}_{\mathrm{KCl}}$ in April, and $\mathbf{d ~ p H _ { \mathrm { KCl } }}$ in August
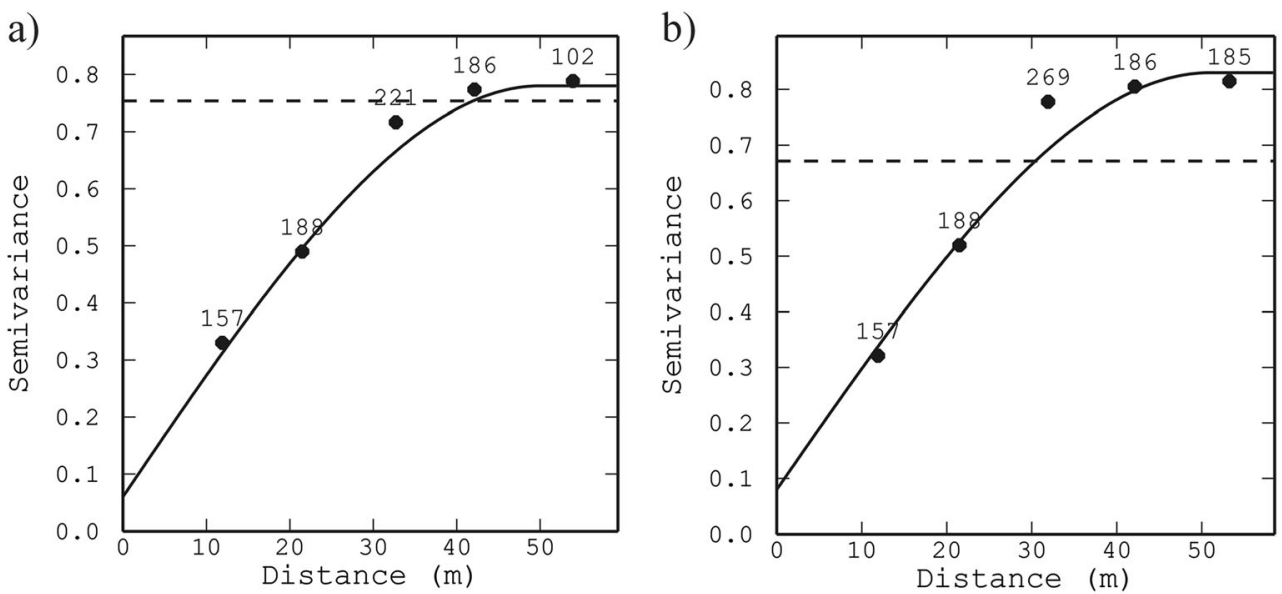

c)

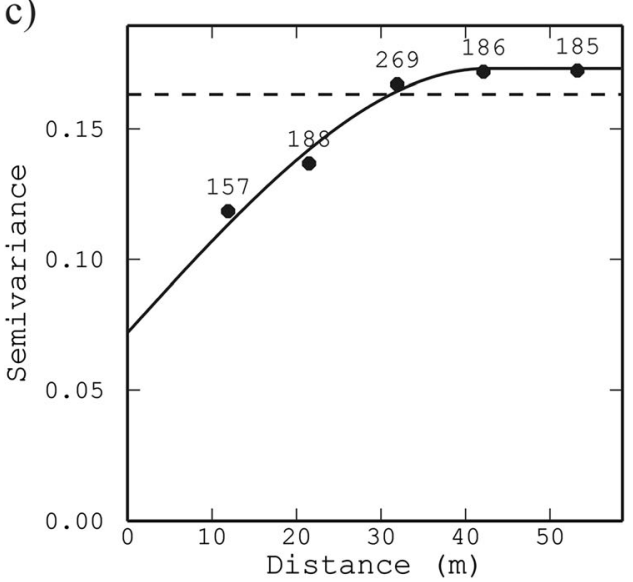

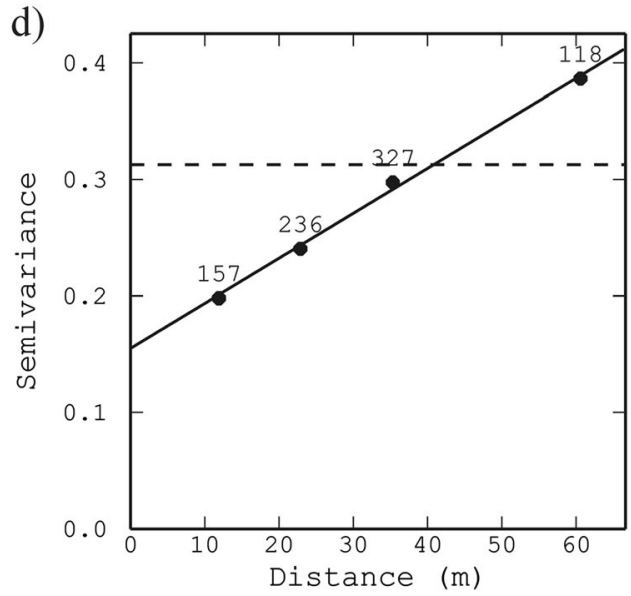

showed a significant coefficient between $\mathrm{P}_{\mathrm{AL}}$ activity and $\mathrm{pH}_{\mathrm{KCl}}$ (a positive relationship) in April and $\mathrm{P}_{\mathrm{AC}}$ and $\mathrm{pH}_{\mathrm{KCl}}$ in August (a negative relationship). The $\mathrm{P}_{\mathrm{AC}}$ and $\mathrm{P}_{\mathrm{AL}}$ activity was negatively correlated $(p=-0.606, p<0.01)$ in the soil samples that were collected in August, while there was no significant relationship between these properties in April.

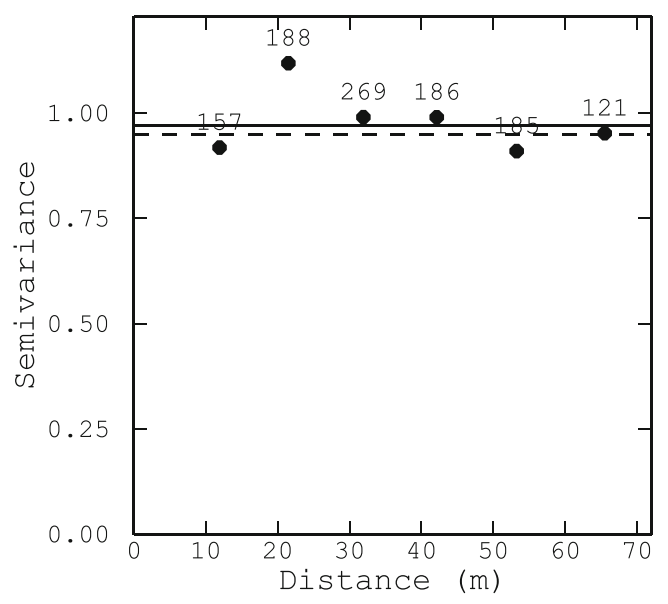

Fig. 5 Experimental semivariogram of clay content in August

\section{Discussion}

\subsection{Inside-population variability of $P$ forms and related enzymes and their stability of patterns over sampling times}

The data of the properties that were measured appeared to be variable within one sampling time as well as between both sampling periods, and a moderate to strong variability was observed. Soil phosphatase activity had the same (moderate) or even higher variability than those of the $\mathrm{P}$ forms (CVs Table 3). The CVs represent the intrinsic heterogeneity that is induced by the soil features and cultivation history (Yanai et al. 2003) and their values are usually higher for biological properties as compared to the physico-chemical properties (Yanai et al. 2003; Piotrowska and Długosz 2012). Soil available $\mathrm{P}\left(\mathrm{P}_{\mathrm{A}}\right)$ data is commonly known to show a high variability (Sun et al. 2003; Roger et al. 2014). The CVs of the available $P$ that were observed in this study were lower than other results that were measured in a small field by Zhou et al. (1996) or in a 112-ha field that was measured by Sun et al. (2003). The available $\mathrm{P}$ that was characterized using different chemical extractions (e.g., $\mathrm{P}-\mathrm{H}_{2} \mathrm{O}, \mathrm{P}-\mathrm{NaHCO}_{3}$ ) in 
a)

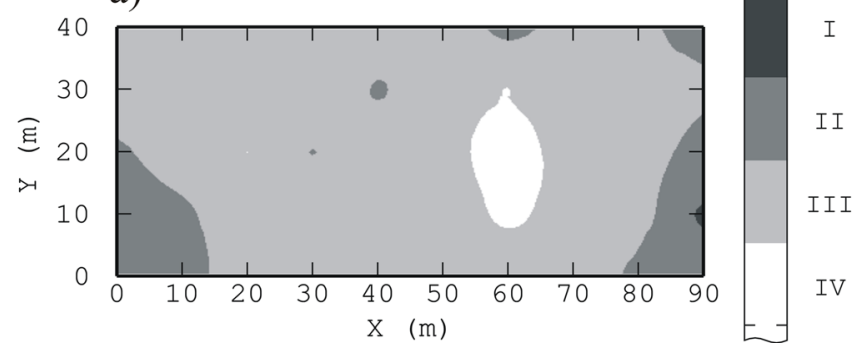

b)

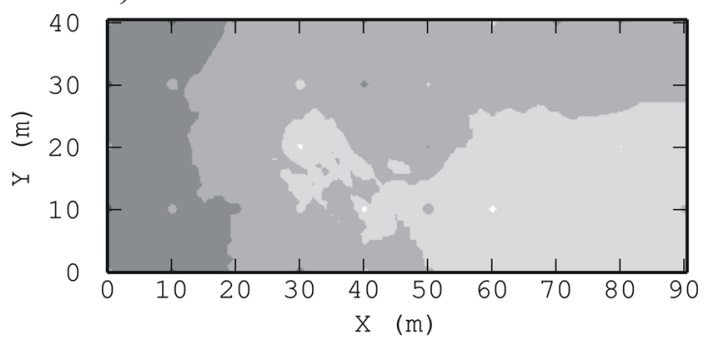

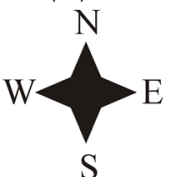

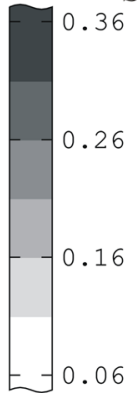

c)

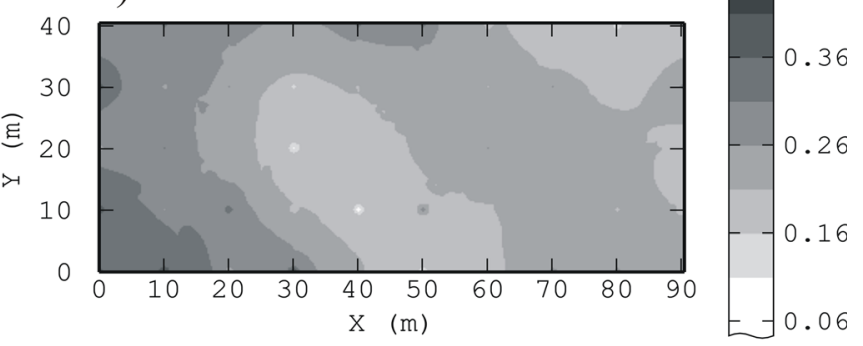

Fig. 6 Spatial distribution of a classes of $\mathrm{P}_{\mathrm{A}}$ concentration (in August), $\mathbf{b} \mathrm{P}_{\mathrm{I}}$ concentration in April, and $\mathbf{c} \mathrm{P}_{\mathrm{I}}$ concentration in August

croplands, permanent grasslands, and mountain pastures had a moderate to high variability with $\mathrm{CV}$ ranging from 43.3 to $120.1 \%$ (Roger et al. 2014).

Soil properties can also be classified according to the extent of their variability in time. Therefore, sampling of the dynamic soil properties at the correct time is critical for the accuracy of site-specific farming. The dynamic properties that exhibit seasonal and annual variation include inorganic and available forms of nutrients and soil biological properties, i.a. enzymatic activity (Štípek et al. 2004; Piotrowska and Długosz 2012). a)

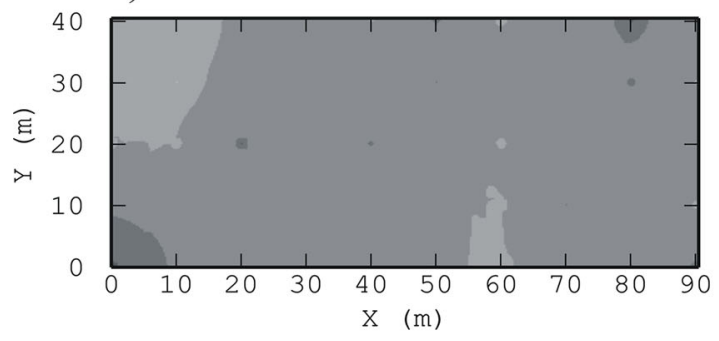

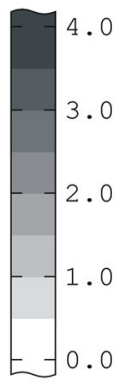

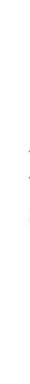

b)

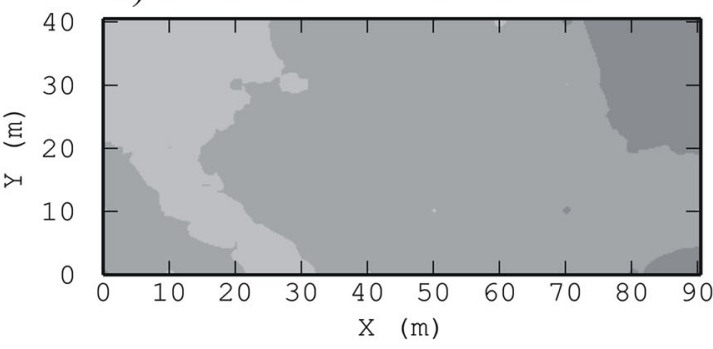

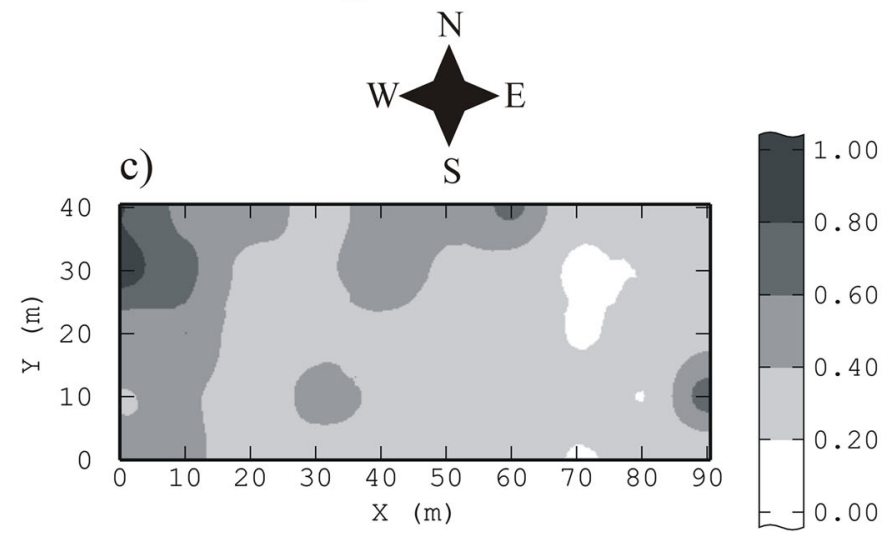

Fig. 7 Spatial distribution of a $\mathrm{P}_{\mathrm{AC}}$ activity in April, $\mathbf{b} \mathrm{P}_{\mathrm{AC}}$ activity in August, and $\mathbf{c} \mathrm{P}_{\mathrm{AL}}$ activity in August 
a)

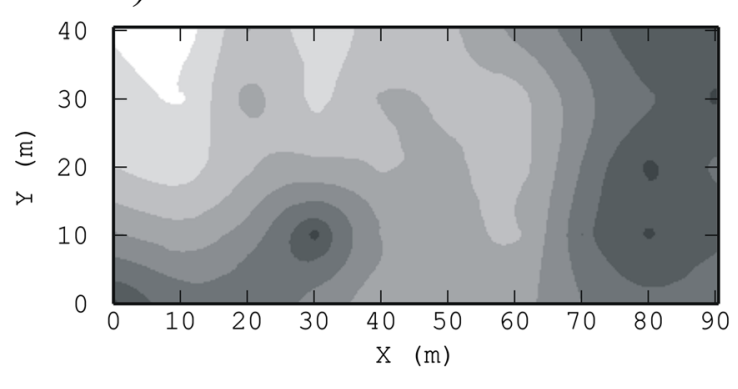

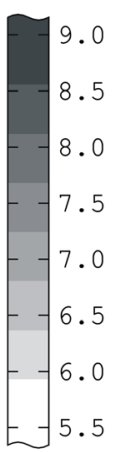

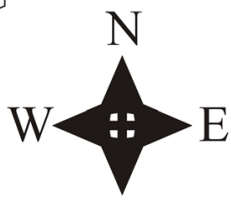

$\mathrm{S}$ b)

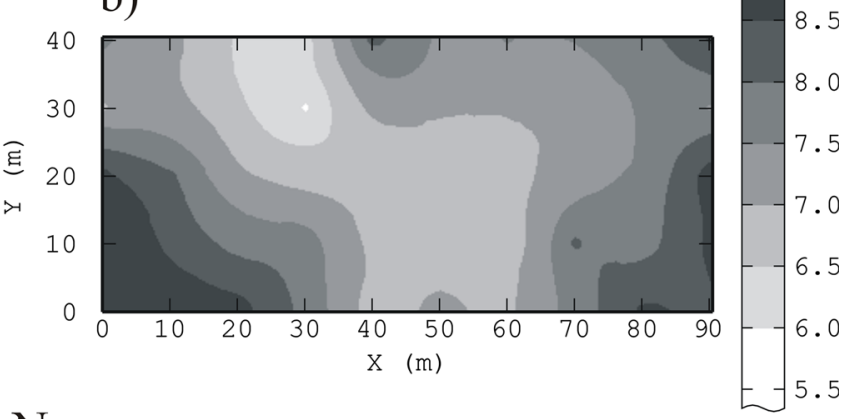

c)

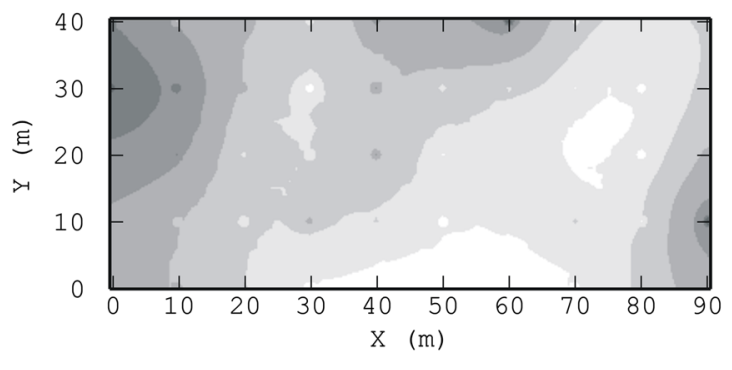

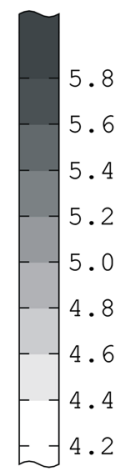

d)

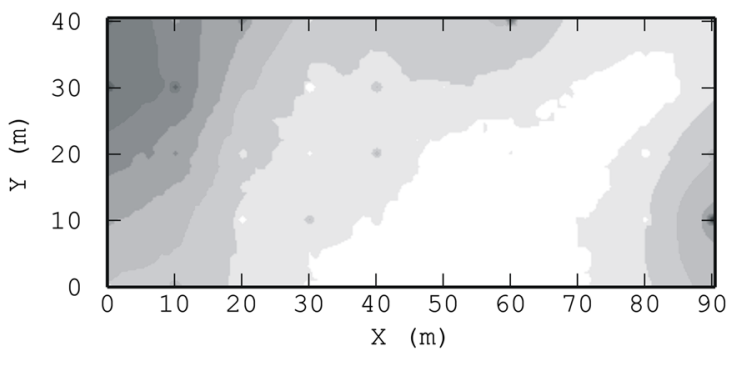

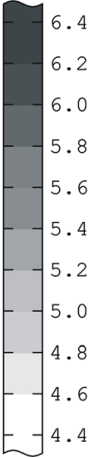

Fig. 8 Spatial distribution of a TOC concentration in April, b TOC concentration in August, $\mathbf{c} \mathrm{pH}_{\mathrm{KCl}}$ in April and $\mathbf{d} \mathrm{pH} \mathrm{KCl}_{\mathrm{K}}$ in August

Soil receives phosphorus annually from plant residues and fertilizers. Because these inputs and the removal of $\mathrm{P}$ by plant uptake vary with crop age and soil temperature and moisture, seasonal variations in the amount and distribution of $\mathrm{P}$ in soils can occur (Shen et al. 2011; Suñer et al. 2014). In this study, not only $P_{I}$ concentration was lower in April compared to August but $\mathrm{P}_{\mathrm{T}}$ concentration was also lower, which was probably caused by a considerable intake of $\mathrm{P}$ from the fertilizer by the intensively growing winter wheat plants and the limited rate of mineralization of $\mathrm{P}_{\mathrm{O}}$ due to low temperatures and little rainfall (Fig. 1). The seasonal changes in the concentration of different $P$ forms in arable soils indicate that the mineralization of labile organic P occurs (Magid and Nielsen 1992; Zhao et al. 2009). Indeed, in this study, the ratio $\mathrm{P}_{\mathrm{O}} / \mathrm{P}_{\mathrm{T}}$ was $15 \%$ lower in August than in April, which indicated that the process of the mineralization of $\mathrm{P}_{\mathrm{O}}$ in plant residues occurred between April and August, which resulted in a higher $\mathrm{P}_{\mathrm{I}}$ and $\mathrm{P}_{\mathrm{T}}$ concentration in August than in April in contrast to the phosphatase activity, which had less activity in August than in April. However, a significant, negative relationship between the $\mathrm{P}_{\mathrm{I}}$ and $\mathrm{P}_{\mathrm{T}}$ content and phosphatase activity was not observed. Several other studies have reported a reduction in soil organic $\mathrm{P}$ fraction during crop growth (Tiessen et al. 1982; Bowman et al. 1999). Sharpley (1985) found that the mineralization of $\mathrm{P}_{\mathrm{O}}$ contributed amounts of $\mathrm{P}$ similar to that of added inorganic fertilizers.

Seasonal variation in phosphatase activities has been demonstrated in a number of studies (e.g., Boerner et al. 2005; Piotrowska-Długosz and Wilczewski 2014). Seasonal variation in the activity, especially in the case of acid phosphatase, is associated with the different stages of plant growth (Dotaniya et al. 2014; Piotrowska-Długosz and Wilczewski 2014). In our study, increased phosphatase activity was observed during the intensive growth of winter wheat (April) compared to August. The effect of plants in different stages of growth can be direct when the roots secrete varying amount of acid phosphatase, and indirect when it is related to changes in soil organic matter content caused by different patterns of continuously producing and excreting organic compounds, such as amino acids, organic acids, sugars and vitamins (Hinsinger et al. 2006), and microbial populations (rhizosphere effect). Microbial communities in the rhizosphere are dynamic and susceptible to changes in plants growth. In response to a change in root exudation patterns with the 
Table 6 Correlation matrix

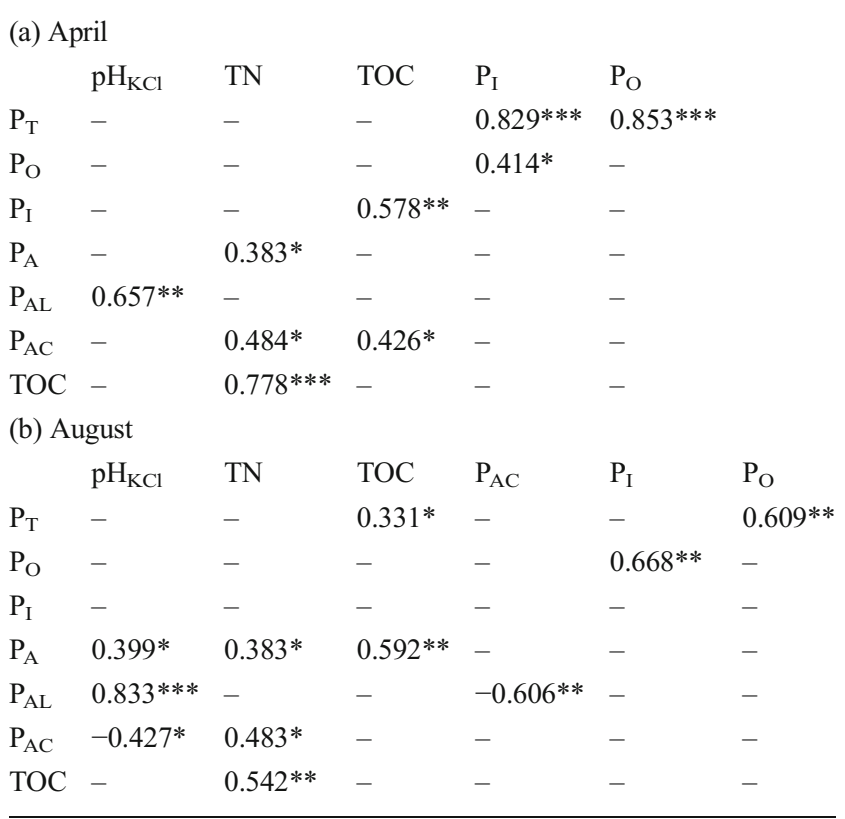

- not significant, $P_{T}$ total phosphorus, $P_{O}$ organic phosphorus, $P_{I}$ inorganic phosphorus, $P_{A}$ available phosphorus, $P_{A L}$ alkaline phosphatase activity, $P_{A C}$ acid phosphatase activity, TOC total organic carbon, $\mathrm{pH}$ soil $\mathrm{pH}$ in $1 \mathrm{M} \mathrm{KCl}$

$* * *$ Correlation is significant at the 0.001 level; $* *$ Correlation is significant at the 0.01 level; *Correlation is significant at the 0.05 level

development of plant, the microbial community structure and composition in the rhizosphere also change with time and varies during the life cycle and with the seasonal response of plants (Germida and Siciliano 2001). Higher enzymatic activity (e.g., phosphatase) was observed during the vigorous growth stage of cucumber while lower activity was noted during the early and late growth stages (Yang et al. 2008). However, Gu et al. (2009) investigated the temporal fluctuations in the activities of dehydrogenase and urease enzymes at different growth stages of two rice varieties and found higher activities at the seedling stage than at the tillering stage.

Temporal variation in the phosphatase activity was also caused by fluctuation in precipitation and temperature (Huang et al. 2011). In this study, however, there was no significant relationship between the weather parameters and phosphatase activity (data not presented), which suggests that other factors were predominant in the functionality of the enzymes.

The data that was obtained in this study showed that there were differences between the April and August sampling times, but probably more often, sampling is required to recognize the real, long-term spatio-temporal structure of soil properties, especially during the intensive soil management and vigorous growth of plants. Some soil properties are very changeable over time and more frequent sampling would probably reveal the variability as well. This is highly probable especially in the case of soil biological properties, e.g., enzymatic activity, which could differ significantly from one month to another (Paz-Ferreiro et al. 2011). The shape of the spatial structure of given soil properties is very complex and is the result of different management factors, the type of crop being grown, climate, and weather conditions (soil moisture, soil temperature), which acting together, contribute to seasonal variation.

\subsection{Spatial variability of $P$ forms and phosphatase activity}

It is commonly known that soil properties vary spatially even over short distances. Spatial variability is known to have an effect on the transport processes in soils (Søvik and Aagaard 2003), biomass turnover rate (Harden and Joergensen 2000), and nutrient cycling processes (Corre et al. 2002). Consequently, assessing the spatial structure of a soil will help to develop better nutrient management strategies and can serve as a means for planning suitable sampling patterns (Stein and Ettema 2003) Two geostatistical indictors of spatial variability were used in this study (Table 5, Figs. 2, 3, 4, 5). One was the nugget/sill ratio, which indicates the spatial structure at the sampling scale and allows for a comparison of the relative size of the nugget effect among different soil properties (Cambardella et al. 1994). All of the properties analyzed in this study, which were spatially autocorrelated, indicated a positive nugget, which can be explained by sampling error, short range variability, and random and inherent variability (Sun et al. 2003). The nugget effect for $\mathrm{P}_{\mathrm{A}}$ did not exceed $12 \%$, and for TOC was lower than $10 \%$, which indicated a strong spatial structure. This result suggests that these properties were highly influenced by intrinsic variations in the soil characteristics, such as texture and mineralogy (Cambardella et al. 1994) and was less sensitive to extrinsic factors. However, we could not estimate the relationship between the content of clay fraction and other properties, since the clay fraction showed a random variability (a pure nugget effect). A significantly higher contribution of nugget variance in the total variance (48-84 \%) of $\mathrm{P}_{\mathrm{A}}$ (Mehlich 3 ) was shown by Daniels et al. (2001) in pastures that had been amended with animal waste. Similarly, in the study of Aggelopoulou et al. (2011), $P_{\text {OLSEN }}$ revealed a pure nugget effect (100\% nugget effect) in an apple orchard in Greece.

The weak spatial dependence for $\mathrm{P}_{\mathrm{I}}$ indicates an extrinsic variability, for example, due to human activity such as fertilization (Geypens et al. 1999). In fact, it could also be caused by the influence of the inorganic $\mathrm{P}$ fertilizer (containing $\mathrm{P}-\mathrm{PO}_{4}{ }^{3-}$ ) that had been applied in autumn in the previous year. The weak spatial structure of $\mathrm{P}_{\mathrm{I}}$ in April means that this variable can almost be predicted from the mean of random samples, whereas in the soil that was collected in August the prediction of $\mathrm{P}_{\mathrm{I}}$ can be improved by the knowledge of the spatial structure within the autocorrelation range of $39 \mathrm{~m}$ (Table 5). 
Another parameter of soil spatial variability is the range $(\mathrm{m})$, which is considered to be the distance beyond which observations are not spatially dependent. Generally, samples need to be taken at a distance shorter than the range of the variogram in order to develop reliable maps (Sun et al. 2003). Results obtained in this study (range values, Table 5) suggested that the strategies that are chosen to create the sampling scheme (every $10 \mathrm{~m}$ ) for the properties studied were not suitable and less intensive sampling grid should be recommended for this field. The similarity of range values between the soil properties can indicate the strength of their relationship. A previous study showed that changes in enzyme activity preceded that of organic matter (Bergstrom et al. 1998a). Some enzymes such as arylsulfatase and phosphatase were strongly spatially related to the organic matter content (Bergstrom et al. 1998b). The similarity in the range between phosphatase and the $\mathrm{P}$ content in this study (Table 5, $\mathrm{P}_{\mathrm{T}}, \mathrm{P}_{\mathrm{I}}$, and $\mathrm{P}_{\mathrm{AC}}$ in April as well as $\mathrm{P}_{\mathrm{I}}$ and $\mathrm{P}_{\mathrm{AC}}$ in August) is also worth pointing out because of the dependence of the synthesis and regulation of phosphatase activities on the $\mathrm{P}_{\mathrm{I}}$ content.

\subsection{Correlations among the properties studied}

Some studies have been devoted to examining the relationship between different forms of soil $\mathrm{P}$ and the activity of enzymes of the $\mathrm{P}$ cycle and the results have been varied with positive, negative, or no correlations being reported (Miller et al. 2001; Wang et al. 2011; Orczewska et al. 2012). A significant but negative relationship between both of these parameters is often shown in soil on which P fertilizers are applied, and/or in naturally fertile soil (Miller et al. 2001). The inverse relationship between phosphatase activity and the available $\mathrm{P}$ content confirms the thesis that the production and activity of soil phosphatases is connected with the demand for $\mathrm{P}$ of microorganisms and plants (Wang et al. 2011). Phosphatases are typical adaptive enzymes and their activity increases while the plant's available P content decreases. Kinetics studies have indicated that orthophosphate ions, which are the product of the reaction that is conducted by the phosphatases, are a competitive inhibitor of their activity in soil (Hui et al. 2013). Other studies have found a significant correlation between phosphatase activity and the available P content (Orczewska et al. 2012). In this study, similar to observation made by Wang et al. (2011), no significant relationship was observed between any $\mathrm{P}$ form and phosphatase activity, which suggested that P may not limit the system that was studied and that some other masking factors such as site geology may influence enzyme production and activity (Olander and Vitousek 2000).

The activities of soil alkaline and acid phosphatase are closely related to soil $\mathrm{pH}$, with acid phosphatase dominating in acid soils and alkaline phosphatase in alkaline soils (Nannipieri et al. 2011). In our study, the $\mathrm{P}_{\mathrm{AL}}$ activity was approximately four times lower than the $\mathrm{P}_{\mathrm{AC}}$ activity, mainly because soil $\mathrm{pH}$ was in the acid range (Table 2). A significant relationship between soil phosphatase activity and soil $\mathrm{pH}_{\mathrm{KCl}}$ was observed in this study, whereas $\mathrm{P}_{\mathrm{AL}}$ was positively related and $\mathrm{P}_{\mathrm{AC}}$ was negatively related (Table 6 ). The above properties also revealed the spatial relationship what was shown in the kriged maps of $\mathrm{P}_{\mathrm{AL}}$ and $\mathrm{P}_{\mathrm{AC}}$ activities and $\mathrm{pH}$ data both in April and August (Figs. 7a-c, 8c-d). The area with higher $\mathrm{pH}_{\mathrm{KCl}}$ values has corresponded with lower $\mathrm{P}_{\mathrm{AC}}$ activity and with higher $\mathrm{P}_{\mathrm{AL}}$ activity. Such correlations were expected since phosphatases have a characteristic $\mathrm{pH}$-dependent activity profile. Soil $\mathrm{pH}$ ranging from 4.8 to 6.8 in April and from 5.0 to 7.0 in August could be a possible source of the variability of soil phosphatases in this study.

\section{Conclusions}

The research showed that the spatial characteristics of the soil properties varied greatly by their position in the plot and the sampling time. For some $\mathrm{P}$ forms $\left(\mathrm{P}_{\mathrm{T}}\right.$ in August, $\mathrm{P}_{\mathrm{O}}$ on both sampling dates), no spatial patterns were observed using our sampling strategy, and therefore, evaluation of their spatial characteristics would require a higher density of sampling.

All of the properties that had a spatial autocorrelation showed nugget variance, which indicated that they were strongly or moderately spatially dependent and were to some degree differentiated by internal factors like soil texture and mineralogy. The findings from this study can be used as a scientific basis for understanding and predicting the contribution of internal factors (i.e., soil type) on the total variability of soil properties, which can mask the influence of soil management practices (fertilization, crop rotation, tillage).

The analysis of variance showed a significant temporal variability in the soil $\mathrm{P}_{\mathrm{T}}, \mathrm{P}_{\mathrm{I}}$ concentration, and soil phosphatase activity, while $\mathrm{P}_{\mathrm{O}}$ and $\mathrm{P}_{\mathrm{A}}$ did not vary significantly between April and August. Seasonal variability was observed in the spatial pattern of the $\mathrm{P}_{\mathrm{I}}$ content and $\mathrm{P}_{\mathrm{AC}}$ activity and there were no similarities in the patterns of their variability that were measured on the same sampling dates or for the same property that was studied during both sampling periods. A variation in time could significantly affect the spatial variability and consequently change the shape of semivariograms of these variables. The data on spatio-temporal variation showed that it is important to take spatial variability into consideration in the sampling strategy. If the sampling had been performed in varying patterns from one date to another, considerable spatial variation could have been superimposed on the temporal changes. More frequent sampling, at least several times throughout the growing season, must be included in the experimental planning in order to gain a better understanding of 
whether $\mathrm{P}$ forms and related enzymes show any permanent spatial patterns in soil ecosystem all of the time or are more randomized.

Acknowledgments The research was financially supported by the Polish Ministry of Science and Higher Education (project no N 310030 32/ 1588). Much gratitude is due to Michele Simmons for proof reading the article.

Open Access This article is distributed under the terms of the Creative Commons Attribution 4.0 International License (http:// creativecommons.org/licenses/by/4.0/), which permits unrestricted use, distribution, and reproduction in any medium, provided you give appropriate credit to the original author(s) and the source, provide a link to the Creative Commons license, and indicate if changes were made.

\section{References}

Aggelopoulou KD, Pateras D, Fountas S, Gemtos TA, Nanos GD (2011) Soil spatial variability and site-specific fertilization maps in an apple orchard. Precis Agric 12:118-129

Așkin T, Kizilkaya R (2006) Assessing spatial variability of soil enzyme activities in pasture topsoils using geostatistics. Eur J Soil Biol 42: 230-237

Atreya KS, Sharma RM, Bajracharya NP (2008) Developing a sustainable agro-system for central Nepal using reduced tillage and straw mulching. J Environ Manag 88:547-555

Barton AP, Fullen MA, Mitchell DJ (2004) Effects of soil conservation measures on erosion rates and crop productivity on subtropical Ultisols in Yunnan province, China. Agric Ecosyst Environ 104: 343-357

Bergstrom DW, Monreal CM, Millette JA, King DJ (1998a) Spatial dependence of soil enzyme activities along a slope. Soil Sci Soc Am J 62:1302-1308

Bergstrom DW, Monreal CM, King DJ (1998b) Sensitivity of soil enzyme activities to conservation practices. Soil Sci Soc Am J 62: 1286-1295

Bishop TFA, Lark RM (2006) The geostatistical analysis of experiments at the landscape-scale. Geoderma 133:87-106

Boerner REJ, Brinman JA, Smith A (2005) Seasonal variations in enzyme activity and organic carbon in soil of a burned and unburned hardwood forest. Soil Biol Biochem 37:1419-1426

Bowman RA, Vigil MF, Nielsen DC, Anderson RL (1999) Soil organic matter changes in intensively cropped dryland systems. Soil Sci Soc Am J 63(1):186-191

Burgess TM, Webster R (1980) Optimal interpolation and isarithmic mapping of soil properties I. The semi-variogram and punctual kriging. J Soil Sci 31:315-331

Burt R (2004) Soil Survey laboratory methods manual. Soil Survey Investigations Report No. 42, version 4.0, USDA-NRCS, Lincoln, Nebraska

Cambardella CA, Moorman TB, Novak JM, Parkin TB, Karlen DL, Turco RF, Konopka AE (1994) Field-scale variability of soil properties in Central Iowa soils. Soil Sci Soc Am J 58:1501-1511

Cobo JG, Dercon G, Yekeye T, Chapungu L, Kadzere C, Murwira A, Delve R, Cadisch G (2010) Integration of mid-infrared spectroscopy and geostatistics in the assessment of soil spatial variability at landscape level. Geoderma 158:398-411

Corre MD, Schnabel RR, Stout WL (2002) Spatial and seasonal variation of gross nitrogen transformation and microbial biomass in a Northeastern US grassland. Soil Biol Biochem 34:445-457

Dalal RC (1997) Soil organic phosphorus. Adv Agron 29:83-117
Daniels MB, Delaune P, Moore PA, Mauromoustakos A, Chapman SL, Langston JM (2001) Soil phosphorus variability in pastures: implications for sampling and environmental management strategies. J Environ Qual 30:2157-2165

Davis JC (1986) Statistics and data analysis in geology. Wiley, New York

Dotaniya ML, Kushwash SK, Rajendiran S, Coumar MV, Kundu S, Subba Rao A (2014) Rhizosphere effect of kharif crops on phosphatases and dehydrogenase activities in a typic haplustert. Natl Acad Sci Lett 37(2):103-106

Egner H, Riehm H, Domingo WR (1960) Studies concerning the chemical analysis of soils as background for soil nutrient assessment. II. Chemical extracting methods to determinate the phosphorous and potassium content of soil (in German). Kungl Lantbrukshögskolans Ann 26:199-215

Garten CT Jr, Kanga S, Dj B, Schadta CW, Zho J (2007) Variability in soils properties at different spatial scales $(1 \mathrm{~m}-1 \mathrm{~km})$ in a deciduous forest ecosystem. Soil Biol Biochem 39:2621-2627

Germida J, Siciliano S (2001) Taxonomic diversity of bacteria associated with the roots of modern, recent and ancient wheat cultivars. Biol Fertil Soils 33:410-415

Geypens M, Vanongeval L, Vogels N, Meykens J (1999) Spatial variability of agricultural fertility parameters in a gleyic podzol of Belgium. Precis Agric 1:319-326

Goovaerts P (1998) Geostatistical tools for characterizing the spatial variability of microbiological and physico-chemical soil properties. Biol Fertil Soils 27:315-334

Gu Y, Wang P, Kong CH (2009) Urease, invertase, dehydrogenase and polyphenoloxidase activities in paddy soil influenced by allelopathic rice variety. Eur J Soil Biol 45:436-441

Harden T, Joergensen RG (2000) Relationship between stimulated spatial variability and some estimates of microbial biomass turnover. Soil Biol Biochem 32:315-334

Hinsinger P, Plassard C, Jaillard B (2006) Rhizosphere: a new frontier for soil biogeochemistry. J Geochem Explor 88:201-213

Huang W, Liu J, Zhou G, Zhang D, Deng Q (2011) Effects of precipitation on soil acid phosphatase activity in three successional forests in southern China. Biogeosciences 8:1901-1910

Hui D, Mayes MA, Wang G (2013) Kinetic parameters of phosphatase: a quantitative synthesis. Soil Biol Biochem 65:105-113

IUSS Working Group WRB, 2007. World reference base for soil resources 2006 - first update 2007. World Soil Resources Reports No. 103. FAO, Rome.

Jung WK, Kitchen NR, Sudduth KA, Andrson SH (2006) Spatial characteristics of claypan soil properties in an agricultural field. Soil Sci Soc Am J 70:387-1397

Kaiser DE, Mallarino AP, Haq MU (2009) Runoff phosphorus loss immediately after poultry manure application as influenced by the application rate and tillage. J Environ Qual 33:299-308

Katsalirou E, Deng S, Nofziger DL, Gerakis A, Fuhlendorf SD (2010) Spatial structure of microbial biomass and activity in praire soil ecosystems. Eur J Soil Biol 46:181-189

Kerry R, Oliver MA (2007) Comparing sampling needs for variograms of soil properties computed by the method of moments and residual maximum likelihood. Geoderma 140:383-396

Kulczycki G (2012) The effect of phosphorus and potassium precision fertilization upon changes in the content of the soluble form of these elements in soil. Fragm Agron 29:70-82

Magid J, Nielsen NE (1992) Seasonal variation in organic and inorganic phosphorus fractions of temperate-climate sandy soil. Plant Soil 144:155-165

Makarov MI, Malysheva TI, Haumaier L, Alt HG, Zech W (1997) The forms of phosphorus in humic and fulvic acids of a toposequence of alpine soils in the northern Caucasus. Geoderma 80:61-73

Mehta NC, Legg JO, Goring CA, Black CA (1954) Determination of organic phosphorus in soils. Soil Sci Soc Am Proc 44:443-449 
Miller SS, Liu J, Allan DL, Menzhuber CJ, Fedorova M, Vance CP (2001) Molecular control of acid phosphatase secretion into the rhizosphere of proteoid roots from phosphorus-stressed white lupin. Plant Physiol 127:594-606

Mocek A, Drzymała S, Maszner P (1997) Genesis, analysis and classification of soils. University Publisher, Poznań University of Life Sciences, Poznań (in Polish)

Moran P (1948) The interpretation of statistical maps. J R Stat Soc: Ser B 10:243-251

Mulla DJ, McBratney AB (2000) Soil spatial variability. In: Malcolm E, Sumner J (eds) Handbook of soil science. CRC Press, Boca Raton, pp A321-A352

Nannipieri P, Giagnoni L, Landi L, Renella G (2011) Role of phosphatase enzymes in soil. In: Bünemann EK, Oberson A, Frossard E (eds) Phosphorus in action, 1st edn. Springer, Berlin, pp 215-243

Olander LP, Vitousek PM (2000) Regulation of soil phosphatase and chitinase activity by $\mathrm{N}$ and $\mathrm{P}$ availability. Biogeochemistry 49(2): 175-191

Olibone D, Rosolem CA (2010) Phosphate fertilization and phosphorus forms under no-till. Sci Agric 67:465-471

Orczewska A, Piotrowska A, Lemanowicz J (2012) Soil acid phosphomonoesterase activity and phosphorus forms in ancient and postagricultural black alder [Alnus glutinosa (L.) Gaertn.] woodlands. Acta Soc Bot Pol 81(2):81-86

Paz-Ferreiro J, Trasar-Cepeda C, del Carmen LM, Seoane S, Gil-Sotres F (2011) Intra-annual variation in biochemical equilibrium of different grassland soils under contrasting management and climate. Biol Fertil Soils 47:633-645

Peigné J, Vian JF, Cannavacciuolo M, Bottollier B, Chaussod R (2009) Soil sampling based on field spatial variability of soil microbial indicators. Eur J Soil Biol 45:488-495

Piotrowska A (2011) Spatial variability of total and mineral nitrogen content and activities of the N-cycle enzymes in a Luvisol topsoil. Pol J Environ Stud 20(6):1565-1573

Piotrowska A, Długosz J (2012) Spatio-temporal variability of microbial biomass content and activities related to some physicochemical properties of Luvisols. Geoderma 173-174:199-208

Piotrowska-Długosz A, Wilczewski E (2014) Soil phosphatase activity and phosphorus content as influence by catch crops cultivated as green manure. Pol J Environ Stud 23(1):157-165

Piotrowska-Długosz A, Rybacki M, Długosz J, Kobierski M, Wilczewski E (2013) Spatial differentiation of total nitrogen content and the activity of N-transforming enzymes in a soil. Ecol Chem Eng 20(6):663-674

PN-R-04023 (1996) Chemical and agricultural analysis (in Polish). PWN Press, Warsaw

Ribaudo MO, Gollehon NR, Agapoff J (2003) Land application of manure by animal feeding operations: is more land needed? J Soil Water Conserv 62:375-389

Roger A, Libohova Z, Rossier N, Joost S, Maltas A, Frossard E, Sinaj S (2014) Spatial variability of soil phosphorus in the Fribourg canton, Switzerland. Geoderma 217-218:26-36

Sebai TE, Lagacherie B, Soulas G, Martin-Laurent F (2007) Spatial variability of isoproturon mineralizing activity within an agricultural field: geostatistical analysis of simple physicochemical and microbiological soil parameters. Environ Pollut 145:680-690

Sharpley AN (1985) Phosphorus cycling in unfertilized and fertilized agricultural soils. Soil Sci Soc Am J 49:905-911
Shen J, Yuan L, Zhang J, Li H, Bai Z, Chen X, Zhang W, Zhang F (2011) Phosphorus dynamics: from soil to plant. Plant Physiol 156:9971005

Søvik AK, Aagaard P (2003) Spatial variability of a solid porous framework with regard to chemical and physical properties. Geoderma 113:47-76

Stein A, Ettema CH (2003) An overview of spatial sampling procedures and experimental design of spatial studies for ecosystem comparisons. Agric Ecosyst Environ 94:31-47

Stevenson FJ (1986) Cycles of soil carbon, nitrogen, phosphorus, sulphur, micronutrient. Wiley, New York

Štípek K, Vaněk V, Száková J, Černý J, Šilha J (2004) Temporal variability of available phosphorus, potassium and magnesium in arable soil. Plant Soil Environ 50(12):547-551

Sun B, Zhou S, Zhao Q (2003) Evaluation of spatial and temporal changes of soil quality based on geostatistical analysis in the hill region of subtropical China. Geoderma 115:85-99

Suñer L, Galantini J, Minoldo G (2014) Soil phosphorus dynamics of wheat cropping systems in the semiarid region of Argentina. Appl Environ Soil Sci, vol. 2014, ID 532807, 1-6

Tabatabai MA, Bremner JM (1969) Use of $p$-nitrophenylophosphate for assay of soil phosphatase activity. Soil Biol Biochem 1:301-307

Tiessen H, Stewart JWB, Bettany JR (1982) Cultivation effects on the amounts and concentrations of carbon, nitrogen and phosphorus in grassland soils. Agron J 74:831-835

Turner BL, Haygarth PM (2005) Phosphatase activity in temperate pasture soils: potential regulation of labile organic phosphorus turnover by phosphodiesterase activity. Sci Total Environ 344:27-36

Vance CP, Uhde-Stone C, Alllan DL (2003) Phosphorus acquistation and use: critical adaptations by plants for securing a nonrenewable resource. New Phytol 157:423-447

Vitousek PM, Porder S, Houlton BZ, Chadwick OA (2010) Terrestrial phosphorus limitation: mechanisms, implications, and nitrogenphosphorus interactions. Ecol Appl 20(1):5-15

Wang JB, Chen ZH, Chen LJ, Zhu AN, Wu ZJ (2011) Surface soil phosphorus and phosphatase activities affected by tillage and crop residue input amounts. Plant Soil Environ 57(6):251-257

Wilding LP (1985) Spatial variability: its documentation, accommodation, and implication to soil surveys. In: Nielsen DR, Bouma J (eds) Soil spatial variability. Pudoc, Wageningen, pp 166-194

Yanai J, Sawamoto T, Oe T, Kusa K, Yamarkawa K, Sakamoto K, Naganawa T, Inubushi K, Hatano R, Kosaki T (2003) Spatial variability of nitrous oxide emission and their soil-related determining factors in an agricultural field. J Environ Qual 32:1965-1977

Yang L, Li T, Li F, Lemcoff JH, Cohen S (2008) Fertilization regulates soil enzymatic activity and fertility dynamics in a cucumber field. Sci Hortic 116:21-26

Zhang S, Huffman T, Zhang X, Liu W, Liu Z (2014) Spatial distribution of soil nutrient at depth in black soil of Northeast China: a case study of soil available phosphorus and total phosphorus. J Soils Sediments 14:1775-1789

Zhao Q, Zeng DH, Fan ZP, Yu ZY, Hu YL, Zhang J (2009) Seasonal variation in phosphorus fractions in semiarid sandy soils under different vegetation types. For Ecol Manag 28:1376-1382

Zhou HZ, Gong ZT, Lamp J (1996) Study on soil spatial variability. Acta Pedol Sin 33:232-241 (in Chinese) 